\title{
State Supervisors' Perceptions of Teacher Efficacy Regarding Alternatively Certified/Licensed Secondary Agriculture Teachers
}

Joshua E. Rice

West Virginia University

Follow this and additional works at: https://researchrepository.wvu.edu/etd

\section{Recommended Citation}

Rice, Joshua E., "State Supervisors' Perceptions of Teacher Efficacy Regarding Alternatively Certified/ Licensed Secondary Agriculture Teachers" (2012). Graduate Theses, Dissertations, and Problem Reports. 3495.

https://researchrepository.wvu.edu/etd/3495

This Dissertation is protected by copyright and/or related rights. It has been brought to you by the The Research Repository @ WVU with permission from the rights-holder(s). You are free to use this Dissertation in any way that is permitted by the copyright and related rights legislation that applies to your use. For other uses you must obtain permission from the rights-holder(s) directly, unless additional rights are indicated by a Creative Commons license in the record and/ or on the work itself. This Dissertation has been accepted for inclusion in WVU Graduate Theses, Dissertations, and Problem Reports collection by an authorized administrator of The Research Repository @ WVU.

For more information, please contact researchrepository@mail.wvu.edu. 
State Supervisors' Perceptions of Teacher Efficacy Regarding Alternatively Certified/Licensed Secondary Agriculture Teachers

\author{
Joshua E. Rice
}

Dissertation submitted to the Davis College of Agriculture, Natural Resources, and Design at West Virginia University in partial fulfillment of the requirements

for the degree of

Doctor of Philosophy

in

Resource Management and Sustainable Development

Major: Human \& Community Development

Stacy A. Gartin, Ph.D., Chair

Douglas D. LaVergne., Ph.D.

John E. Kessell, Ed.D.

Eugene E.D. Felton, Ph.D.

Robert A. Dailey, Ph.D.

Division of Resource Management

Morgantown, West Virginia

2012

Key Words: Vocational Education, Agriculture, Education 


\begin{abstract}
State Supervisors' Perceptions of Teacher Efficacy Regarding Alternatively Certified/Licensed Secondary Agriculture Teachers
\end{abstract}

\author{
Joshua E. Rice
}

The purpose of this study was to identify state supervisors' perceptions of teacher efficacy regarding alternatively certified/licensed secondary agriculture teachers. The researcher focused on state supervisors' perception of alternatively certified/licensed teachers' efficacy in relationship to classroom/laboratory, supervised agriculture experience programs, and the National FFA organization. The researcher chose to conduct descriptive survey. Forty five states expressed that they offered alternative certification/licensure $(\mathrm{N}=45)$. The population consisted of all state supervisors of agriculture educators as listed by the 2010-2011 approved list from the American Association for Agricultural Education and the National Association of Supervisors of Agricultural Education. State supervisors disagreed that alternatively certified/licensed teachers were performing up to standards in regards to supervised agriculture experience programs. The researcher also found a statistical significance in relation to the community population in which the alternatively certified teacher was teaching in and the performance data for classroom/laboratory and FFA activities. 


\section{DEDICATION}

This dissertation is dedicated to the individuals who walk into agriculture education classrooms throughout the United States in an attempt to make a difference in the lives of young people every day. It is also dedicated to my family and friends who have supported my ever endeavor. 


\section{ACKNOWLEDGEMENTS}

I would like to thank my parents, Glen and Trisha, my Grandparents, Warren and Rosalie for all of their help and support throughout the years. You have always been there to remind me that I can accomplish anything that I set my mind to. You have all instilled in me the beliefs that as long as I try I cannot fail. You have truly shaped me into the person that I am today and the person that I will be tomorrow.

To my committee; you are an incredible group of scholars and friends. I have learned so much from each of you. I have always felt welcomed and that I could stop in and talk to you about anything. I have truly enjoyed the precious time that we have spent together discussing the educational profession and the role that we can each play to ensure a bright future for those who have the desire to learn. I could not have attained this goal without you. The work that we have done together is better because we all worked together.

To Dr. Stacy Gartin, you have impacted my life in ways that words can hardly describe. You have always encouraged me to try an idea that I have had and I can hardly remember a time that you have told me "no". Instead, we would sit down and discuss the idea, weigh the pros and cons, and you would support my decision. You are much more than a professor; you are a mentor, an inspiration, and a true friend. None of this would be possible without you.

To Dr. LaVergne, I have truly enjoyed getting to know you as a teacher and a friend. You bring to work a sense of confidence and intellect that makes me believe in myself and the future of agriculture education. I truly feel fortunate to know you. There are so many things that you have taught me not only about education but also about life.

To my fiancée and soon to be wife, Andrea, you have been someone that I can always depend on to show me guidance and encouragement. You were always willing to help me collect my thoughts and you are the best proof reader in the world. I am so fortunate to have you in my life and you make me a better person and teacher. 
ABSTRACT ii

DEDICATION...................................................................

ACKNOWLEDGEMENTS ................................................ iv

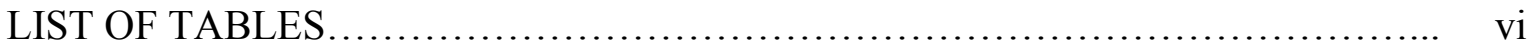

LIST OF FIGURE.......................................................... vii

CHAPTER I Introduction........................................................ 1

Statement of the Problem.............................................. 7

Purpose and Objectives............................................... 7

Limitations of the Study ............................................. 8

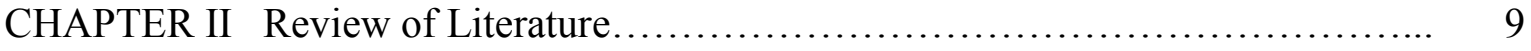

CHAPTER III Methodology............................................... 16

Purpose and Objectives.................................................. 16

Methods................................................................. 16

Analysis of Data...................................................... 19

Use of Findings.................................................... 19

CHAPTER IV Findings.................................................. 20

Purpose and Objectives.............................................. 20

Results.............................................................. 20

CHAPTER V Conclusions and Recommendations............................... 29

Purpose and Objectives............................................... 29

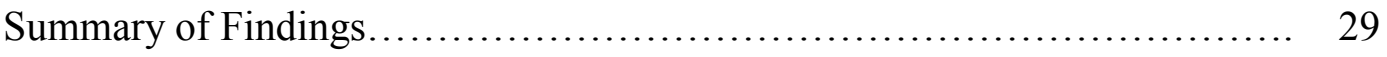

Recommendations.................................................. 32

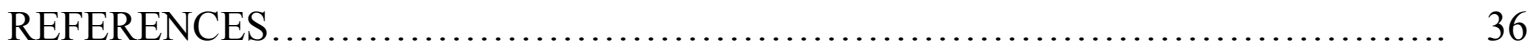

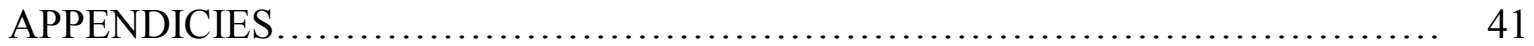

APPENDIX A: Phase 1 Questionnaire.................................. 42

APPENDIX B: State Phone Call Script 46

APPENDIX C: Cover Letter......................................... 48

APPENDIX D: Phase II Questionnaire.................................... 50

APPENDIX E: Follow-Up Cover Letter.............................. 60

APPENDIX F: Individual State Certification/Licensure Information.......... 63

CURRICULUM VITAE ....................................................... 85 


\section{LIST OF TABLES}

Table Title Page

$1 \quad$ Characteristics of Alternatively Certified/Licensed Teachers............. 22

2 State Supervisors Perceptions of Alternatively Certified/Licensed Agriculture teachers in regards to the following Classroom \& Laboratory Related Statements.......................................

3 State Supervisors Perceptions of Alternatively Certified/Licensed Agriculture teachers in regards to the following SAE Related Statements. 25

$4 \quad$ State Supervisors Perceptions of Alternatively Certified/Licensed Agriculture teachers in regards to the following FFA Related Statements .................................................................

$5 \quad$ Comparing Mean Scores of Population Demographics of the Communities in which Alternatively Certified/Licensed Teachers Work...

6 ANOVA Table of Performance of Alternatively Certified/Licensed Agriculture Teachers by Age... 


\section{LIST OF FIGURES}

Figure Title Page

$1 \quad$ Participating State Supervisors................................. 30

$2 \quad$ Individual State Certification/Licensure Requirements..................... 31 


\section{Chapter 1}

\section{Introduction}

Throughout history, advancements have led to significant changes in the agriculture industry. The invention of the wheel, the moldboard plow, genetically modified organisms, and the global positioning systems are all examples of technologies that have shaped agriculture. Behind every great invention there was a mind at work, and some form of education shaped all of those great minds. Education opens new pathways on the road to success and the evolution of the world that we live in today can be testament to the achievements that were made by great minds.

Marcus Tullius Cicero, a philosopher, scholar, and teacher, played a major role in the advancement of the Roman Empire. Cicero was a major advocate of education and is quoted as once saying the following about education: "What nobler employment, or more valuable to the state, than that of the man who instructs the rising generation."(Everitt, p. 254)

Cicero understood that in order for the Romans to continue to improve their empire they would need skilled workers, farmers, and leaders to build the social structure that would be required for success. Cicero knew that the foundation of civilization rested on the effectiveness of the education system that motivated students to continually ask the question, "Why"? Students, who are motivated and encouraged to ask questions, seek new answers and solutions to the world's problems are those individuals who hold the keys to open the door to the future.

Public school agricultural education originated around 1858 with the introduction of vocational training in two Massachusetts schools (Hamlin, 1962). Supervised agricultural experience (SAE) was probably the first component of the agricultural education model to be developed in the form of youth apprenticeships to skilled tradesmen (Croom, 2008, p. 113). Moore (1988) expressed that Rufus W. Stimson, principal of the Smith Agricultural School experienced significant achievement in establishing the SAE component by applying concepts learned in class to their home farms. Agricultural clubs started forming in schools to help students share ideas and discuss academics (Berry, 1924). The Passage of the Smith Hughes Act in 1917 provided 
funding for the supervision by the state departments of education to monitor the vocational agricultural classes that were being taught in high schools and helped to pave the way for the development of a national agriculture organization, the Future Farmers of America, now known as the National FFA Organization (FFA).

The structure and components that encompass agricultural education have continually evolved into the total program that is used today. Cook (1947) was one of the first to identify five components that should be included in the agricultural education model: classroom instruction, supervised farming programs, farm mechanics, FFA, and farmer classes. In 1949, Hamlin provided his view of what the agricultural model should include: classroom teaching, supervised practice, and the FFA. In 1952, Phipps and Cook co-authored a book that outlined the program components that they felt should be included in the agricultural model: classroom activities, supervising farming programs, farm mechanics activities, training in food preservation and the FFA.

Today, the predominant model for organizing instruction in agricultural education involves the interrelationships between three major concepts: classroom and laboratory instruction, supervised agricultural experience, and agricultural youth organization participation (Phipps, Osborne, Dyer \& Ball, 2008). Classroom and laboratory are those activities that provide learning experiences within the confines of a school facility (Croom, 2008, p. 110). Instructional content includes agricultural mechanics, animal science, plants and soil science, agricultural economics, horticulture, agricultural production and biotechnology (Talbert, Vaughn, \& Croom, 2006). The foundation of the students' agricultural knowledge is fostered through use of cognitive learning, problem solving, and practical scenarios. Laboratories provide opportunities for the students to take the knowledge learned in the classroom and, through the use of psychomotor skills, further develop their understanding of the subject area. Common agricultural related laboratories include, but are not limited to agriculture mechanics, greenhouse, aquaculture, hydroponics, biotechnology, and land laboratories.

The second component is a supervised agricultural experience program (SAE). The SAE is an independent learning program for students enrolled in agricultural education courses designed to provide learning experiences in the agricultural career pathway of choice (Croom, 2008, p. 10). The SAE is constructed with input from the 
student, the employer, parents/guardians and agriculture teacher. The learning and experience for the SAE takes place outside of the typical constructs of the classroom and laboratory setting. The student is required to keep accurate records of their SAE experiences. The SAE component helps students exercise the concepts that were acquired during classroom and laboratory instruction. Students are recognized for their hard work through opportunities that are provided through the FFA. The SAE component is also required for membership in the FFA (National FFA, n.d. a).

The National FFA Organization is the third component of the total program. The FFA is an instructional tool that complements both instruction and the SAE components by encouraging students to perform well academically (Croom, 2008, p. 110). "The FFA is a youth organization that helps students develop their potential for premier leadership, personal growth, and career success through agricultural education (National FFA, n.d. c)." Students can take part in a variety of competitions that highlight their knowledge of agriculture. Career Development Events (CDEs) are competitions among FFA members that create connections between classroom instruction and real-life scenarios building on what is learned in agricultural classes and the FFA. The events are designed to help prepare students for careers in agriculture. Classroom instruction comes alive as students demonstrate their skills in a competitive setting in which the abilities of individuals and teams are tested in 24 major areas of agricultural instruction. (National FFA, n.d. d)

Students also have the opportunity to develop communication and teamwork skills while pursuing various degrees that range from the discovery degree to the chapter, state, and American FFA degrees (National FFA, n.d. a). Each FFA chapter is required to develop a program of activities (POA) that serves as a road map for planning activities and accomplishing goals on the local level while focusing on three categories: student development, chapter development, and community development (National FFA, n.d. b). Each FFA chapter should develop a POA that is specific to their particular chapter.

The educational system was designed to facilitate learning for youth by presenting them with relevant information and techniques that would help ensure them a place and occupation in society. In agricultural education the concept of learning by doing is a key component in the classroom, which helps students apply and retain the skills that are addressed through the use of hands-on demonstrations. These hands-on demonstrations 
help the students conceptualize the relevance of the lesson, and they can apply the concept to a post high school job setting (Phipps, Osborne, Dyer \& Ball, 2008). According to Larry Case, former Coordinator of Agriculture and Rural Education in the United States Department of Education, "The key to our success in agricultural education is to have an adequate supply of well prepared people motivated to help prepare students for successful careers in Agriculture, Food and Natural Resources industries" (Case, personal communication, Sept. 20, 2007).

When considering the extent of the responsibilities that an agriculture teacher is accountable for, the method in which teachers are certified/licensed must be examined to understand the teacher's preparedness. The two primary methods that are used today to prepare agriculture teachers: traditional certification and alternative certification.

Every state has its own procedures for certifying teachers and every public school is expected to hire teachers certified by the state. "Certification always involves exams, often in both general knowledge and teaching skills, and it nearly always involves coursework and practice teaching" (Boyd et al., 2007, p. 46). Each state sets its requirements to determine if teachers are qualified and have met certification requirements. Boyd et al. (2007) expressed that "no national database collects information on the coursework or other aspects of the preparation of individual teachers" but some states are starting to collect data on the structure and content of teacher preparation programs (p. 46).

The National Research Center for Career and Technical Educational (2007) outlined traditional certification as follows:

Most traditional teacher certification/licensure programs offered by colleges and universities have the same basic requirements. Students complete a specified number of hours in university general education courses, such as English composition, college algebra, history, and psychology. In addition, students develop a content specialty such as mathematics, physical education, or business education through contentarea coursework. Finally, as part of teacher preparation, students take courses in teaching pedagogy and complete field experiences and supervised student teaching. Some certification/licensure programs are 
found only at the graduate level, usually as a master's of education program. Students in these programs have usually earned a baccalaureate degree in a subject area and complete the courses in teaching pedagogy as the primary focus of the master's degree. An exit test may be required for initial certification/licensure for individuals in either the alternative or traditional certification/licensure tracks. The traditional route is more likely to require exit tests, such as the Praxis II. (p. 6)

Boyd et al. (2007) categorized the required course work for traditional certification into three areas: foundational courses, pedagogical courses and content or subject-matter knowledge (p. 48). The foundational courses could include psychology, child development, and history of education. The pedagogy courses would encompass classes similar to classroom management, teaching methods and the subject matter courses specific to the desired certification area. While most programs are thought to require teaching/classroom experience, only thirty-eight states require beginning teachers to have field experiences, such as student teaching (Boyd et al., 2007, p. 50).

Teachers who are not certified through a traditional certification program often seek alternative teacher certification. Alternate route programs now prepare nearly one out of every five teachers, and forty-seven states now offer teachers alternate routes into the teaching profession (Walsh, Thomas, \& Thomas B. Fordham Foundation, 2007, p. 13). In a study conducted by Rocca and Washburn (2006), the 47 states with alternative teacher certification reported approximately 538 certification programs other than traditional university teacher programs (p. 59). Alternative routes to certification typically allow teachers to enter the classroom by postponing or bypassing many of the criteria required by traditional teacher preparation programs (Boyd et al., 2007, p. 51).

Similar to traditional certification, alternative certification requirement are set by the individual state and vary by state. Boyd et al. (2007) illustrate some of the requirements of various alternative certification programs:

All alternative certification programs require teachers to hold a bachelor's degree; 80 percent require teachers to demonstrate subject matter knowledge by completing coursework or passing an exam, or both. 
Programs require that pre-service teachers complete course work in pedagogy, methods of teaching, and field experiences....

In Texas, applicants must have a bachelor's degree with at least a 2.5 grade point average and must prove competency in reading, writing, and math either through coursework or minimum scores on standardized tests such as the ACT, SAT, or GRE. The largest alternative teacher certification program in the country is the New York City Teaching Fellows Program which was established in 2000. The program requires applicants to have a bachelor's degree with at least a 3.0 grade point average. Once assigned a teaching position, they must begin an approved master's degree program that will qualify them for continuing certification in their subject area. The fellows program supplies about 25 percent of new hires in New York City. (p. 53)

Alternative teacher certification also incorporates testing into the requirements. Similarly to the traditional preparation pathways, the most common assessments were the Praxis Series. Praxis I (reading, writing, and math), Praxis II Subject Assessment (content) and Praxis III (leanring and teaching), assessments of classroom performance, are typically required (Zirkle et al., 2007, p. 14). In addition to course work and test scores, some programs require that teachers have occupational work experience.

Regardless of the certification route that a teacher has chosen, he/she must understand the components of an effective classroom and must have the tools necessary to be a quality educator. The success of the students that occupy the classroom is dependent upon the knowledge and preparedness of their teacher. State supervisors and local boards of education have to ensure that students are receiving a quality education. The teacher is the facilitator of the learning that must take place. Understanding the ways that teachers are prepared and their performance, once they are in the classrooms, can help to identify the best practices in preparing future educators. 


\section{Statement of the Problem}

Accumulation of trade skills in the workforce equips an individual with more than just technical skills; people are exposed to social interactions and possess a better understanding of how those skills relate to the social network of the world. The individuals returning to secondary education may be able to perform skills that would meet the technical psychomotor skills that a college class would require; it is the pedagogy of that skill that might need to be further developed in order to effectively communicate that skill to students in high school classrooms, laboratories, supervised agriculture experience programs, and the students active participation in the National FFA Organization.

\section{Purpose and Objectives}

The purpose of this study was to identify state supervisors' perceptions of teacher efficacy regarding alternatively certified/licensed secondary agriculture teachers. The objectives were:

1. Determine if state supervisors perceive alternatively certified/licensed agriculture educators to be competent in regards to pedagogy strategies?

2. Determine if state supervisors perceive alternatively certified/licensed agriculture educators to be competent in regards to supervised agriculture experience programs?

3. Determine if state supervisors perceive alternatively certified/licensed agriculture educators to be competent in regards to participation in the National FFA Organization?

This study also sought to determine if relationships existed between the alternatively certified/licensed teachers abilities and the population of the community in which they taught and the age of the alternatively certified/licensed teacher. Based on the literature, the following hypotheses were developed to be tested a priori at the .05 level. $\mathrm{Ho}_{1}$ : No difference existed between state supervisor's perceptions of the performance of alternatively certified/licensed teachers' abilities in regards to classroom and laboratory, SAE, and FFA based upon the population of the community in which the alternatively certified/licensed teacher teaches. 
$\mathrm{Ho}_{2}$ : No difference existed between state supervisor's perceptions of the performance of alternatively certified/licensed teachers' abilities in regards to classroom and laboratory, SAE, and FFA based upon the age of the alternatively certified/licensed teacher teaches.

\section{Limitations of the Study}

- The researcher assumes that the state supervisors are basing their responses on observations they are making of the alternatively certified/licensed teacher.

- The criterion on which the state supervisors provided his/her responses is based on personal values, beliefs and experience.

- The researcher assumed that the state supervisors understand the components of the total program of agriculture education (classroom and lab, SAEs, FFA). 


\section{Chapter II}

\section{Review of Literature}

Institutions of higher education focus on potential teachers developing their own educational philosophies and pedagogy skills that they will need to be successful as they enter into the public school system. Traditional teacher preparation programs are the primary source of teachers in most states. These programs are shaped by a combination of state regulations, the criteria of accreditation groups, and the choices made by individual programs and institutions (Boyd, Goldhaber, Lankford, \& Wyckoff, 2007).

Institutions of higher education convey techniques that include the ability to effectively communicate concepts and develop educational teaching strategies that can be used to teach high school students. During the pre-service teacher's formative education, the primary focus is not on being able to use the concept at a mastery level, but rather to possess the ability to teach others the basic knowledge and proper use of the concept so the student will have the desire to seek further information and training. One expert (Ashburn, 1984) noted the following: "traditional certification, the process of preparing teachers, teacher education institutions and state departments of education "certify" that certain graduates have met specific minimum standards and that those individuals should be awarded their teaching license." (p. 2)

In the past, due to the high demand and low supply of highly qualified agricultural education teachers, emergency or alternative certification was an accepted practice. Teacher shortages throughout the 1970s forced states to literally issue "emergency" credentials (Walsh et. al, 2007, p. 16). Changes in the labor market were responsible for a majority of the labor shortages; opportunities for women and minorities to enter into other avenues than teaching caused fewer of them to enter into the teaching profession (Walsh et. al, 2007, p. 17). To deal with the shortages, states tried to attract more and different people to teaching by reducing entry requirements and introducing alternative certification programs (Boyd et. al, 2007, p. 46).

Today, there is still a shortage of agriculture teachers still exists due to the low income of teachers in the overall scheme of the U.S. work force. Alternate routes are established for a variety of reasons (Feistritzer \& Chester, 1998): to provide accessibility to the teaching workforce for nontraditional entrants, attract teachers to underserved 
geographical areas, recruit teachers for subject areas of perennial shortage such as science and math, attract high potential individuals that might otherwise pursue different careers (Darling-Hammond \& Cobb, 1996). Alternative certification sees people who enter teaching under this system as learning on the job under certain conditions determined by the particular policy in question (Hawley, 1985).

Stoddard and Floden (1995) suggest nontraditional alternative certification programs are a way to upgrade teaching standards already degraded by teaching shortages. According to the 2002 U.S. secretary of education's annual report on teacher quality, "Teachers certified through alternative routes ... are more apt to take challenging assignments" (U.S. Department of Education, 2002, p. 16).

A common aim of nontraditional alternative certification programs is to concentrate teacher preparation in a smaller amount of time, even though some of these programs have similar expectations in content, rigor, and outcomes compared to traditional programs (Stoddart \& Floden, 1995). Since candidates are usually screened for subject matter competence before being accepted into a nontraditional alternative program, the programs often focus on teaching methods and classroom management (Adcock \& Mahlios, 2005).

One of the best known alternative certification programs is the Teach for American program. Started in 1990, the program focuses on a five week summer training course to prepare the students to be teachers. To enter the program, participants must have a bachelors degree and have a cumulative grade point average of 2.5 on a 4.0 scale. The participants teach students for two hours each day and receive extensive lesson plan training from Teach for America instructors. The participants also take classes on curriculum development, classroom management and teaching methods. To date, there are more than 8,200 Teach for America members and more than 500,000 students impacted annually by the program. (Teach for America, 2011)

Some educators are concerned that the continued use of emergency certification and the miss-assignment of teachers will compromise the quality of education that students need and deserve. Therefore, nontraditional alternative certification programs, which prepare teachers, are a viable option where there is a shortage of teachers (National Commission on Teaching and America's Future, 1996). Stoddart and Floden (1995) 
quoted Feistritzer concerning nontraditional teacher certification: "What began as a shortterm measure to deal with teacher shortages is now becoming an institutionalized alternative to college-based teacher education" (p. 1).

There are social pressures that have a direct impact on the importance of having an alternate means to certify teachers. In an attempt to provide quality education to more students, the National FFA proposed the $10 \times 15$ goal. The $10 \times 15$ goal stated the following:

By 2015 there will be in operation 10,000 quality agricultural science education programs serving students through an integrated model of classroom/laboratory instruction, experiential learning, and leadership and personal skill development. Further, all students will be members of the FFA and have a supervised agricultural experience that supports classroom and laboratory instruction. (Fleet, 2007)

The introduction of No Child Left Behind (NCLB) also put some pressure on the way that teachers were certified in agricultural education. Martin, Fritzsche and Ball (2006) conducted a study to determine the impact of NCLB on secondary agricultural education programs. One of the perceived impacts of NCLB on agricultural education from the studies was that the certification of provisional agricultural teachers will be adversely affected because of the NCLB legislation's requirement for highly qualified teachers (Martin et. al, 2006, p. 107).

Participants in nontraditional alternative programs are more likely to be older, a member of a minority group, and male, who have had past experiences in other occupations (Shoho \& Martin, 1999). Rocca and Washburn (2006) found that alternatively certified teachers were on average ten years older than traditionally certified teachers and that $28 \%$ possessed advanced degrees. Sandlin et al. (1993) concluded that alternative route programs must recognize the different types of students they attract and the condition under which these students work, and develop program curriculum appropriate to their needs. Reichardt (2002) noted another concern in regards to the retention of teachers that are alternatively certified in a research study that he conducted by stating: "Alternative teacher education offers a low-cost method of entering teaching and thus is attractive to those who view teaching as a short-term career" (p. 10). 
Adcock and Mahlios (2005) noted that in nontraditional alternative teacher certification programs, the curriculum is designed with the academic background of the student in mind and usually requires from one to two additional years of education beyond the baccalaureate degree. Shen (1997) found that over $50 \%$ of alternative certification teachers came right out of college and another $23.8 \%$ already held teaching or other education-related positions.

Most nontraditional alternative certification programs require intensive supervision and mentoring of the teacher candidate from the institution offering certification. Typically, the pedagogical courses are concentrated and restructured, and often times are held in the evenings and on weekends to accommodate the work schedules of those seeking nontraditional alternative certification (Miller, McKenna, \& McKenna, 1998). Research suggests that pedagogical content knowledge plays a very important role in teaching and that teacher's without teacher education who are certified alternatively have more difficulties learning to teach than those certified traditionally (Darling-Hammond, 1990). In a study conducted by Ingersoll (2002), new teachers who had pedagogical preparation as well as clinical practice before they began teaching were more likely to stay in teaching.

Teachers who have completed certification through an alternative method might be proficient in the subject matter area that they are teaching, but they might not have the ability to effectively communicate the knowledge that they possess. Success or failure of an individual recruited from industry is a highly individual matter (Knight \& Moore, 1980). Knobloch and Whittington (2002) found novice agriculture teachers who had teaching and student teaching experience were more confident than teachers with a lack of such experience.

In 1964, Gerlock conducted a study at Florida State University that compared administrator's evaluations of selected professionally and provisionally certified secondary school teachers. The research population included all white secondary school teachers in Florida; $(n=201)$ were professionally certified and $(n=140)$ were certified provisionally. Gerlock addressed personal qualifications, teaching ability, and relationships with others, professional ethics and performance, moral and social ethics and performance. 
Gerlock (1964) summarized that there were no significant differences between professionally and provisionally certified teachers in regards to personal qualifications, relationships with others, and professional ethics. Gerlock did, however, find that significant differences existed in the areas of teaching skills as well as moral and social ethics. Professionally certified teachers scored measurably higher than provisionally certified teachers in both categories.

Darling-Hammond and Cobb (1996) asserted that fully prepared and certified teachers are generally more highly rated and more successful with students than teachers without full preparation (p. 41). Turley and Nakai's (2000) review of several studies indicated that teachers who complete traditional pre-service preparation before beginning teaching are superior to alternate route teachers on virtually every dimension of teaching, including classroom management, curriculum development, repertoire of teaching strategies, knowledge of students, awareness of differing learning styles, and ability to assess for evaluative as well as instructional planning purposes. Ashton (1996) concluded that teachers with regular state certification receive higher supervisor ratings and have higher student achievement than teachers who do not meet certification standards (p. 21).

Prior experience is a factor that can influence the effectiveness of an individual who has received an alternative means of certification in terms of his/her ability to convey key points and procedures onto those whom he/she will be sharing their knowledge base. The real issue is not the source of the teachers but the methods of preparation which are used to identify and prepare teachers recruited from industry (Knight \& Moore, 1980). Rocca and Washburn (2006) found that alternatively certified teachers had an average of 7.6 years of industry experience while traditionally certified teachers had an average of one year of industry experience.

The barometer by which most teachers are evaluated is the recognition that they receive from their fellow teachers at the school where they teach as well as the other educational professionals that are in the same specialized field. Teachers who are certified through an alternative means could potentially be viewed differently by their peers than someone who had completed the traditional certification process. Adelman, Michie, and Bogart (1986) expressed that in a study they conducted surrounding 
alternative certification, traditionally certified teachers who were interviewed about the alternative certification process were supportive of alternatively certified teachers; however, several of the alternatively certified participants reported negative responses from peers who were traditionally certified and their supervisors also expressed the presence of hostile and cynical reactions towards the alternatively certified teachers from their traditionally certified peers.

Classroom management and the professional development that occurs between a teacher and a student could potentially be a hard concept to grasp by someone entering the education field from the labor force. The age and maturity difference that exists between the adults that the educator formerly worked with and the secondary school students that the education professional would currently work with would be significantly different and could be a hard transition to make.

In his thesis that investigated the Characteristics of West Virginia Secondary Agriculture Educators, James Beatty (2004) stated the following in regards to agriculture educators, "Agriculture educators should be held to the highest standards possible to ensure that every agriculture student accomplishes something in all three areas of the program while enrolled." In an earlier study conducted by Miller, Kahler, and Rheault (2002) at Iowa State University they established a few characteristics that are expected in agricultural educators: productive teaching behaviors, organized structured class management, positive interpersonal relationships, professional responsibilities, and personal characteristics (p. 37-38).

An important aspect of agricultural education that is often overlooked is the fact that agricultural educators not only teach in the classroom but also have responsibilities that exceed standard classroom instruction. Some additional competencies that a teacher must possess relate to advising the FFA chapter. Agriculture teachers must be competent in "participating in meetings, advising regarding budget and finances, assisting treasurer with financial records, helping the secretary improve records, instructing reporter in preparing articles, advising committees, assisting in applying for advanced degrees, supervising SAEs and assisting in carrying out special activities" (Phipps \& Osborne, 1988 p.139). 
Duncan and Ricketts (2008), sought to compare total program efficacy between traditionally and alternatively certified agriculture teachers. Their population consisted of 348 middle school and/or high school agriculture teachers employed in Georgia during the 2004-2005 school years. They concluded that traditionally certified teachers were significantly more efficacious in terms of their technical content knowledge in conducting FFA and SAE activities and in regards to program management.

It is important to understand the impact alternatively certified teachers have on the level of achievement and success of students who have received instruction from nontraditionally certified teachers. Laczko-Keer and Berliner (2002) maintain that students of teachers from alternative programs perform lower academically than those taught by traditionally certified teachers. Teachers who are certified through alternative methods can have long term effects on the agriculture education system as a whole. 


\section{Methodology}

\section{Purpose and Objectives}

The purpose of this study was to identify state supervisors' perceptions of teacher efficacy regarding alternatively certified/licensed secondary agriculture teachers. The objectives were:

1. Determine if state supervisors perceive alternatively certified/licensed agriculture educators to be competent in regards to pedagogy strategies?

2. Determine if state supervisors perceive alternatively certified/licensed agriculture educators to be competent in regards to supervised agriculture experience programs?

3. Determine if state supervisors perceive alternatively certified/licensed agriculture educators to be competent in regards to participation in the National FFA Organization?

This study also sought to determine if relationships existed between the alternatively certified/licensed teachers abilities and the population of the community in which they taught and the age of the alternatively certified/licensed teacher. Based on the literature, the following hypotheses were developed to be tested a priori at the .05 level. $\mathrm{Ho}_{1}$ : No difference existed between state supervisor's perceptions of the performance of alternatively certified/licensed teachers' abilities in regards to classroom and laboratory, SAE, and FFA based upon the population of the community in which the alternatively certified/licensed teacher teaches.

$\mathrm{Ho}_{2}$ : No difference existed between state supervisor's perceptions of the performance of alternatively certified/licensed teachers' abilities in regards to classroom and laboratory, SAE, and FFA based upon the age of the alternatively certified/licensed teacher teaches.

\section{Methods}

The researcher chose to conduct descriptive survey research, which is the most widely used type of research. Descriptive research is also known as statistical research and attempts to answer the questions of who, what, when, where, how and why. This 
form of research is often used to collect data that can describe the characteristics of a population or to explain a phenomenon. Descriptive research is not based on an hypothesis, and the variables are not identified as dependent or independent. Researchers who are using statistical research are trying to form generalizations about a population. Data can be collected through mail or online surveys. Dillman's Tailored Design (2007) is one of the most popular methods of data collection that is used.

One of the greatest benefits of statistical research is that the population that is being studied completes the survey while immersed in their natural environment therefore the information that is desired is being collected within the preferred situation. Descriptive research also has weaknesses. Due to the fact that there is no hypothesis, the researcher cannot make predictions about the outcome of the research. Researchers cannot make cause and effect statements based on the data collected and there is typically a lack of internal validity due to a poorly designed or hard to comprehend questionnaire. When creating the instrument, the researcher can only create descriptive and investigative statements. Descriptive research is analyzed by using the measures of central tendency (mean, median, and mode).

The Institutional Review Board at West Virginia University approved this study. Following Dillman's (2007) Tailored Design Method for survey implementation, the researchers implemented a questionnaire using the traditional mailed notification followed by a series of electronic mail (e-mail) reminders. A modified Delphi technique (Dalkey \& Helmer, 1963) was used to develop the questionnaire for the study.

Data were gathered in two phases. Phase one gathered information pertaining to the availability of alternative certification/licensure in each of the 50 states in the US. Phase two consisted of compiling information from the states that identified the existence of an alternative certification/licensure program within their specific state from the data collected from phase one.

To develop the initial questionnaire, the researcher perused current and past research documents (e.g., journal articles, conference proceedings, theses, dissertations, etc.) relating to teacher certification, effective teaching strategies, supervised agriculture experience programs, and teacher involvement with the National FFA Association. Based on a list of specifications constructed by the researcher and developed from the review of 
literature, three emerging categories were selected related to teacher efficacy factors associated with agriculture education.

To establish a set of statements prior to the initial round of data collection, the researchers modified and converted the themes into 49 individualized statements: 17 in regards to classroom and laboratory, 16 in regards to SAEs, and 16 in regards to the National FFA Association. Content and face validity were determined by a panel of university experts who were agricultural educators. Reliability of the instrument was conducted and a post-hoc reliability analysis yielded Cronbach's alpha values for the following constructs: Classroom and laboratory $=.92, \mathrm{SAE}=.97, \mathrm{FFA}=.91$.

A group of four head teacher agricultural educators were chosen to serve as expert panelist. The group provided input regarding the content and direction of the statements, which added to the precision of the instrument. The panelists were selected because they were considered to be experts within the profession of agricultural education teaching. Panelists were contacted and notified of their selection and a request was solicited for their participation. All of the panelists selected (100\%) agreed to participate. Panelists were e-mailed the list of statements immediately after agreeing.

Rounds two and three of the modified Delphi technique consisted of the expert panelists ranking the 49 individualized items using the following scale: $1=$ strongly disagree (SD), 2 = disagree (D), $3=$ agree (A), and $4=$ strongly agree (SA). Each round consisted of providing the expert panelist with statements from the previous round with the exception of the researchers removing any items that were not relevant to the study. Because of the size of the panel and the consensus among the accuracy of the panelists in agreement of the statements, a fourth round was not needed. After the construction of the questionnaire, the researchers were ready to proceed with survey implementation.

The population consisted of all state supervisors of agriculture educators as listed by the 2010-2011 approved list from the American Association for Agricultural Education and the National Association of Supervisors of Agricultural Education. During phase one, the numbers provided for each state were called to determine if they offered a form of alternative certification/licensure for agriculture teachers. Forty five states expressed that they offered alternative certification/licensure $(\mathrm{N}=45)$. 
In phase two, the identified participants were electronically mailed the questionnaire along with an introductory letter describing the goals and confidentiality of the study. For the remainder of the data collection phase, the researchers sent reminder emails every week to encourage participants to complete and return the questionnaire. Nonresponse error was addressed by comparing early respondents to late respondents (Ary et al., 2006). A chi-square test of independence was used to determine whether there was a significant difference between early and late respondents on gender and years of teaching experience. The chi-square values were not significant $(\alpha>.05)$. A conclusion that nonrespondents were similar to respondents was drawn (Ary et al., 2006); hence, generalizations could be made to the entire population. The final response rate was $51 \%$ $(\mathrm{N}=23)$.

\section{Analysis of Data}

Each member of the population was assigned a numerical code prior to the initial mailing. This code enabled the researcher to document each survey received and identify non-respondents. The code was destroyed before the data were analyzed to protect the anonymity of the survey participant.

The data from the returned questionnaires were entered into an excel spreadsheet. The data were transferred to the personal computer version of the Statistical Package for Social Sciences (SPSS) $19^{\text {th }}$ edition. Levels of significance were set at alpha $=<.05$ apriori for all statistical tests. Descriptive analyses were performed on the data, and the appropriate methods of reporting frequencies, standard deviation, and means for each set of data were used. Descriptive analyses including frequencies, percentages and means were used to evaluate numerical data to allow for conversion into narrative form.

\section{Use of Findings}

The findings of this study will be utilized to determine the current teacher preparation methods that are used to alternatively certify/license agriculture education teachers. The results will reflect the opinions of state supervisors on the effectiveness of these practices. The findings will be provided to head state supervisors and head teacher educators as well as other professional agriculture teacher associations. The results will also contribute to the body of knowledge on the continuing challenges facing the preparation of effective agriculture teachers. 


\section{Chapter IV}

\section{Findings}

\section{Purpose and Objectives}

The purpose of this study was to identify state supervisors' perceptions of teacher efficacy regarding alternatively certified/licensed secondary agriculture teachers. The objectives were:

1. Determine if state supervisors perceive alternatively certified/licensed agriculture educators to be competent in regards to pedagogy strategies?

2. Determine if state supervisors perceive alternatively certified/licensed agriculture educators to be competent in regards to supervised agriculture experience programs?

3. Determine if state supervisors perceive alternatively certified/licensed agriculture educators to be competent in regards to participation in the National FFA Organization?

This study also sought to determine if relationships existed between the alternatively certified/licensed teachers abilities and the population of the community in which they taught and the age of the alternatively certified/licensed teacher. Based on the literature, the following hypotheses were developed to be tested a priori at the .05 level. $\mathrm{Ho}_{1}$ : No difference existed between state supervisor's perceptions of the performance of alternatively certified/licensed teachers' abilities in regards to classroom and laboratory, SAE, and FFA based upon the population of the community in which the alternatively certified/licensed teacher teaches.

$\mathrm{Ho}_{2}$ : No difference existed between state supervisor's perceptions of the performance of alternatively certified/licensed teachers' abilities in regards to classroom and laboratory, SAE, and FFA based upon the age of the alternatively certified/licensed teacher teaches.

\section{Results}

The population consisted of all state supervisors of agriculture educators as listed by the 2010-2011 approved list from the American Association for Agricultural Education and the National Association of Supervisors of Agricultural Education. Forty 
five states were identified by the researcher that offer alternative certification/licensure $(\mathrm{N}=45)$. The final response rate for the study was $51 \%(\mathrm{~N}=23)$. Reliability of the instrument was conducted and a post-hoc reliability analysis yielded Cronbach's alpha values for the following constructs: Classroom and laboratory $=.92, \mathrm{SAE}=.97, \mathrm{FFA}=$ .91 .

The state supervisors were asked to identify the mean demographical information of the alternatively certified/licensed teachers that were working in their state. When asked what gender occupied the majority of alternatively certified/licensed teachers, 20 state supervisors (87\%) identified that males occupied the majority of teachers and three state supervisors (13\%) identified that females occupied the majority of alternatively certified/licensed teachers in their state (Table 1). In regards to race, 22 state supervisors $(95.7 \%)$ indicated that the majority of their alternatively certified/licensed teachers were Caucasian while one state supervisor (4.3\%) indicated that the majority of the alternatively certified/licensed teachers were Middle Eastern American.

The respondents were asked to identify the mean age of the alternatively certified/licensed teachers that were working in their state. Three state supervisors (13\%) identified the mean age as less than 25 years of age, 10 state supervisors (43.5\%) identified 26 to 30 years of age, three (13\%) identified 31 to 35 years of age as the mean age, six supervisors (26.1\%) recognized 36 to 40 years of age, and one state supervisors $(4.3 \%)$ indicated that the mean age in their state that was 41 years and older.

State supervisors were also asked to describe the population of the community that the alternatively certified/licensed teachers were teaching within. Nine state supervisors (39.1\%) indicated that the alternatively certified/licensed teachers were teaching in a rural community, 13 supervisors $(56.5 \%)$ conveyed that the alternatively certified/licensed teachers were teaching in an urban community, and one teacher (4.3) expressed that the alternatively certified/licensed teachers were teaching in a metropolitan area.

When evaluating the background experience that alternatively certified/licensed teachers have when entering the profession, state supervisors expressed that $4.3 \%$ of the teachers had no degree, $52.2 \%$ possessed industry experience, $8.7 \%$ had a professional certificate, $4.3 \%$ had a 2 year associates degree, $78.3 \%$ possessed a bachelors degree, 
$4.3 \%$ had a masters degree, and $4.3 \%$ of the alternatively certified/licensed teachers had a professional degree.

\section{Table 1}

Characteristics of Alternatively Certified/Licensed Teachers

\begin{tabular}{|c|c|c|}
\hline & $\mathrm{N}$ & $\%$ \\
\hline \multicolumn{3}{|l|}{ Gender } \\
\hline Male & 20 & 87 \\
\hline Female & 3 & 13 \\
\hline \multicolumn{3}{|l|}{ Race } \\
\hline Caucasian & 22 & 95.7 \\
\hline Middle Eastern American & 1 & 4.3 \\
\hline \multicolumn{3}{|l|}{ Age } \\
\hline$<-25$ Years of Age & 3 & 13 \\
\hline $26-30$ Years of Age & 10 & 43.5 \\
\hline $31-35$ Years of Age & 3 & 13 \\
\hline $36-40$ Years of Age & 6 & 26.2 \\
\hline 41 Years and Over & 1 & 4.3 \\
\hline \multicolumn{3}{|l|}{ Community Demographics } \\
\hline Rural & 9 & 39.2 \\
\hline Urban & 13 & 56.5 \\
\hline Metro & 1 & 4.3 \\
\hline \multicolumn{3}{|l|}{ Background Experience } \\
\hline No Degree & 1 & 4.3 \\
\hline Industry Experience in Agriculture & 12 & 52.2 \\
\hline Professional Certificate & 2 & 8.7 \\
\hline 2 Year Associates Degree & 1 & 4.3 \\
\hline Bachelors Degree & 18 & 78.3 \\
\hline Masters Degree & 1 & 4.3 \\
\hline Professional Degree & 1 & 4.3 \\
\hline
\end{tabular}


The first statement category that was addressed was classroom and laboratory related activities. The state supervisors agreed that alternatively certified/licensed teachers have high expectations for student learning $(M=3.04, S D=.56)$, implement current events and new information into the curriculum $(M=3.00, S D=.30)$, use an interest approach to attract students $(M=2.91, S D=.42)$, use laboratories as an extension of the educational concepts learned in the classroom $(M=2.87, S D=.63)$, engage students in experiential learning $(M=2.87, S D=.55)$ and maintain a positive classroom learning environment $(M=2.83, S D=.65)($ Table 2$)$. State supervisors also agreed that alternatively certified/licensed teachers write measurable objectives $(M=2.70, S D=.56)$, use appropriate assessment strategies to measure student learning $(M=2.65, S D=.57)$, understand and implement technology ( $21^{\text {st }}$ century skills $)$ in the classroom and laboratories $(M=2.57, S D=.66)$, implement higher order thinking into lessons $(M=$ $2.52, S D=.59)$, work with other teachers to teach across the curriculum $(M=2.52, S D=$ $.59)$, and vary the teaching strategies that he/she uses $(M=2.52, S D=.59)$.

State supervisors disagreed that alternatively certified/licensed teachers use appropriate teaching strategies $(M=2.43, S D=.66)$, can effectively construct lesson plans $(M=2.39, S D=.66)$, are aware of the various needs of diverse groups of learners at different ability levels $(M=2.39, S D=.66)$, and construct lessons that are conducive to learning for all types of learners $(M=2.26, S D=.54)$.

The second statement category that was addressed was SAE related activities. The state supervisors disagreed that alternatively certified/licensed teachers promote opportunities in placement settings $(M=2.43, S D=.59)$, explore SAE opportunities with first year students $(M=2.35, S D=.71)$, submit state degree applications for state FFA degrees $(M=2.35, S D=.71)$, and promote SAE opportunities in entrepreneurship $(M=$ $2.35, S D=.65)$ (Table 3). State supervisors also disagreed that alternatively certified/licensed teachers promote entrepreneurship SAEs for students with off-farm agricultural interests $(M=2.30, S D=.64)$, help students find employment opportunities for SAEs $(M=2.30, S D=.56)$, promote the scope and growth of SAEs $(M=2.26, S D=$ $.69)$, involve students in challenging SAEs $(M=2.22, S D=.60)$, promote SAE opportunities in exploratory settings $(M=2.22, S D=.60)$, and involve students in challenging SAEs $(M=2.22, S D=.60)$. 
Table 2

State Supervisors Perceptions of Alternatively Certified/Licensed Agriculture teachers in regards to the following Classroom \& Laboratory Related Statements. $(n=23)$

\begin{tabular}{|c|c|c|}
\hline Statement & $M$ & $S D$ \\
\hline Have high expectations for student learning. & 3.04 & .56 \\
\hline Implements current events and new information into the curriculum. & 3.00 & .30 \\
\hline Uses an interest approach to attract students. & 2.91 & .42 \\
\hline $\begin{array}{l}\text { Uses laboratories as an extension of the educational concepts learned } \\
\text { in the classroom. }\end{array}$ & 2.87 & .63 \\
\hline Engages students in experiential learning. & 2.87 & .55 \\
\hline Maintains a positive classroom learning environment. & 2.83 & .65 \\
\hline Writes measurable objectives. & 2.70 & .56 \\
\hline Uses appropriate assessment strategies to measure student learning. & 2.65 & .57 \\
\hline $\begin{array}{l}\text { Understands and implements technology }\left(21^{\text {st }} \text { century skills }\right) \text { in the } \\
\text { classroom and laboratories. }\end{array}$ & 2.57 & .66 \\
\hline Implements higher order thinking into lessons. & 2.52 & .59 \\
\hline Works with other teachers to teach across the curriculum. & 2.52 & .59 \\
\hline Varies the teaching strategies that he/she uses. & 2.52 & .59 \\
\hline Uses appropriate teaching strategies. & 2.43 & .66 \\
\hline Can effectively construct lesson plans. & 2.39 & .66 \\
\hline $\begin{array}{l}\text { Is aware of the various needs of diverse groups of learners at different } \\
\text { ability levels }\end{array}$ & 2.39 & .66 \\
\hline $\begin{array}{l}\text { Constructs lessons that are conducive to learning for all types of } \\
\text { learners (Audible, Visual, \& Kinesthetic). }\end{array}$ & 2.26 & .54 \\
\hline
\end{tabular}

Note. Scale: $1.00-1.50=\mathrm{SD}, 1.51-2.50=\mathrm{D}, 2.51-3.50=\mathrm{A}, 3.51-4.00=\mathrm{SA}$

Additionally, state supervisors disagreed that alternatively certified/licensed teachers have students submit accurate and complete records of their SAEs $(M=2.17, S D$ $=.65)$, promote SAE opportunities in research $(M=2.13, S D=.63)$, have students apply for proficiency awards each year $(M=2.13, S D=.63)$, require all students have a supervised agricultural experience program $(M=2.00, S D=.52)$, primarily supervise SAEs during summer months $(M=1.96, S D=.56)$ and supervise each student's SAE at least four times a year $(M=1.91, S D=.52)$. 


\section{Table 3}

State Supervisors Perceptions of Alternatively Certified/Licensed Agriculture teachers in regards to the following SAE Related Statements. $(n=23)$

\begin{tabular}{lcc}
\hline Statement & $M$ & $S D$ \\
\hline Promotes opportunities in placement settings. & 2.43 & .59 \\
Explores SAE opportunities with first year students. & 2.35 & .71 \\
Submits state degree applications for state FFA degrees. & 2.35 & .71 \\
Promotes SAE opportunities in entrepreneurship. & 2.35 & .65 \\
Promotes entrepreneurship SAEs for students with off-farm & 2.30 & .64 \\
agricultural interests. & & \\
Helps students find employment opportunities for SAEs. & 2.30 & .56 \\
Promotes the scope and growth of SAEs. & 2.26 & .69 \\
Involves students in challenging SAEs. & 2.22 & .60 \\
Promotes SAE opportunities in exploratory settings. & 2.22 & .60 \\
Involve students in challenging SAEs. & 2.22 & .60 \\
Students submit accurate and complete records of their SAEs. & 2.17 & .65 \\
Promotes SAE opportunities in research. & 2.13 & .63 \\
Students apply for proficiency awards each year. & 2.13 & .63 \\
Require all students have a supervised agricultural experience & 2.00 & .52 \\
program. & & \\
Primarily supervises SAEs during summer months. & 1.96 & .56 \\
Supervises each student's SAE at least four times a year. & 1.91 & .52 \\
\hline
\end{tabular}

Note. Scale: $1.00-1.50=\mathrm{SD}, 1.51-2.50=\mathrm{D}, 2.51-3.50=\mathrm{A}, 3.51-4.00=\mathrm{SA}$

The third statement category that was addressed was National FFA Association related activities. The state supervisors agreed that alternatively certified/licensed teachers have students attend state FFA convention $(M=2.74, S D=.54)$, have students participate in career development events $(M=2.65, S D=.57)$, assist with fund raising for chapter activities $(M=2.65, S D=.49)$, have students pursue an FFA chapter leadership role $(M=2.61, S D=.50)$, holds regularly scheduled meetings $(M=2.57, S D=.59)$, use community resources that are available $(M=2.57, S D=.59)$ and have student engage in state FFA leadership activities $(M=2.52, S D=.51)($ Table 4$)$. 
State supervisors disagree that alternatively certified/licensed teachers FFA membership reflects the demographic make-up of the school $(M=2.48, S D=.59)$, holds an annual parent/member banquet $(M=2.43, S D=.66)$, understands the purpose of the FFA $(M=2.43, S D=.59)$, have students attend national FFA convention $(M=2.39, S D$ $=.58)$, encourages students to participate in public speaking $(M=2.35, S D=.57)$, effectively advises the FFA chapter $(M=2.35, S D=.49)$, promotes the FFA to all students in his/her school $(M=2.30, S D=.56)$, have students pursue an FFA state leadership role $(M=2.17, \mathrm{SD}=.58)$ and requires students to recite the FFA creed $(\mathrm{M}=$ $2.13, \mathrm{SD}=.46)$

\section{Table 4}

State Supervisors Perceptions of Alternatively Certified/Licensed Agriculture teachers in regards to the following FFA Related Statements. $(n=23)$

\begin{tabular}{lcc}
\hline Statement & $M$ & $S D$ \\
\hline Students attend state FFA convention. & 2.74 & .54 \\
Students participate in career development events. & 2.65 & .57 \\
Assists with fund raising for chapter activities. & 2.65 & .49 \\
Students pursue a FFA chapter leadership role. & 2.61 & .50 \\
Holds regularly scheduled meetings. & 2.57 & .59 \\
Uses community resources that are available. & 2.57 & .59 \\
Students engage in state FFA leadership activities & 2.52 & .51 \\
FFA membership reflects the demographic make-up of the school. & 2.48 & .59 \\
Holds an annual parent/member banquet. & 2.43 & .66 \\
Understands the purpose of the FFA. & 2.43 & .59 \\
Students attend national FFA convention. & 2.39 & .58 \\
Encourages students to participate in public speaking. & 2.35 & .57 \\
Effectively advises the FFA chapter. & 2.35 & .49 \\
Promotes the FFA to all students in his/her school. & 2.30 & .56 \\
Students pursue an FFA state leadership role. & 2.17 & .58 \\
Requires students to recite the FFA creed. & 2.13 & .46
\end{tabular}

Note. Scale: $1.00-1.50=\mathrm{SD}, 1.51-2.50=\mathrm{D}, 2.51-3.50=\mathrm{A}, 3.51-4.00=\mathrm{SA}$ 
Independent t-test compared the mean scores for the three areas addressed within the study (classroom and laboratory, SAE, and FFA) in regards to the communities in which the alternatively certified/licensed teacher works. When evaluating the t-test for the classroom and laboratory totals there was a significant difference between teachers who taught in a rural or urban environment $t(20)=-.602, \mathrm{p}<.05$; the results however showed a small effect size $r=.13$ (Table 5). When evaluating the t-test for the SAE totals there was no significant difference $t(20)=-.730, \mathrm{p}>.05$; a small effect size was calculated $r=.16$. When evaluating the t-test for the FFA totals there was a significant difference between teachers who taught in a rural or urban environment $t(20)=1.26, \mathrm{p}<$ .05 ; the result indicated a medium effect size of $r=.27$. Because of the statistically significant differences found between two of the variables (classroom \& laboratory and FFA) the researcher failed to accept $\mathrm{Ho}_{1}$.

\section{Table 5}

Comparing Mean Scores of Population Demographics of the Communities in which Alternatively Certified/Licensed Teachers Work. $(n=23)$

\begin{tabular}{lccccccc}
\hline & \multicolumn{7}{c}{ Rural } \\
\cline { 2 - 8 } & $M$ & $S D$ & $M$ & $S D$ & $t$ & $r$ & $p$ \\
\hline $\begin{array}{l}\text { Classroom } \\
\text { and }\end{array}$ & 2.58 & .60 & 2.69 & .17 & $.602^{*}$ & .13 & .02 \\
Laboratory & & & & & & & \\
SAE & 2.10 & .67 & 2.27 & .39 & .730 & .27 & .15 \\
FFA & 2.58 & .46 & 2.38 & .29 & $1.26^{*}$ & .51 & .05 \\
\hline $\begin{array}{l}\text { Note: } * \alpha \leq .05, \text { Scale: } 1.00-1.50=\mathrm{SD}, 1.51-2.50=\mathrm{D}, 2.51-3.50=\mathrm{A}, 3.51-4.00=\mathrm{SA} \\
{ }^{*} \text { Post hoc analysis was not performed on metropolitan population because there were } \\
\text { fewer than two cases. }\end{array}$
\end{tabular}

A one-way ANOVA was conducted to compare the alternatively certified teachers' performance in regards to classroom and lab, SAE, and FFA, as identified by state supervisors, by age. A Tukey-Krammer post-hoc analysis reveled no significant difference for the classroom and laboratory performance, $F(3,18)=.159, \mathrm{p}>.05, r=.03$ (Table 6). There was no significant difference regarding SAE performance, $F(3,18)=$ $.881, \mathrm{p}>.05, r=.18$. There was no significant difference in regards to FFA performance, $F(3,18)=.648, \mathrm{p}>.05, r=.14$. Because no statistically significant 
differences were found between any of the variables (classroom \& laboratory and FFA)

$\mathrm{Ho}_{2}$ was accepted.

\section{Table 6}

ANOVA Table of Performance of Alternatively Certified/Licensed

Agriculture Teachers by Age. $(\mathrm{n}=23)$

\begin{tabular}{lcccccccccc}
\hline Years of Age & \multicolumn{2}{c}{$<25$} & \multicolumn{2}{c}{$26-30$} & \multicolumn{2}{c}{$31-35$} & \multicolumn{2}{c}{$36-40$} \\
& $M$ & $S D$ & $M$ & $S D$ & $M$ & $S D$ & $M$ & $S D$ & $F$ & $p$ \\
\hline Classroom and & 2.58 & .10 & 2.66 & .54 & 2.58 & .19 & 2.67 & .30 & .159 & .956 \\
Laboratory & & & & & & & & & & \\
SAE & 2.52 & .36 & 2.20 & .57 & 2.08 & .28 & 2.02 & .52 & .881 & .495 \\
FFA & 2.38 & .17 & 2.49 & .37 & 2.27 & .40 & 2.46 & .44 & .648 & .635 \\
\hline
\end{tabular}

Note: ${ }^{*} \alpha \leq .05$. Scale: $1.00-1.50=\mathrm{SD}, 1.51-2.50=\mathrm{D}, 2.51-3.50=\mathrm{A}, 3.51-4.00=\mathrm{SA}$

${ }^{a}$ Post hoc analysis was not performed on 41 years and older because there were fewer than two cases. 


\section{Chapter V}

\section{Conclusions and Recommendations}

\section{Purpose and Objectives}

The purpose of this study was to identify state supervisors' perceptions of teacher efficacy regarding alternatively certified/licensed secondary agriculture teachers. The objectives were:

1. Determine if state supervisors perceive alternatively certified/licensed agriculture educators to be competent in regards to pedagogy strategies?

2. Determine if state supervisors perceive alternatively certified/licensed agriculture educators to be competent in regards to supervised agriculture experience programs?

3. Determine if state supervisors perceive alternatively certified/licensed agriculture educators to be competent in regards to participation in the National FFA Organization?

This study also sought to determine if relationships existed between the alternatively certified/licensed teachers abilities and the population of the community in which they taught and the age of the alternatively certified/licensed teacher. Based on the literature, the following hypotheses were developed to be tested a priori at the .05 level.

$\mathrm{Ho}_{1}$ : No difference existed between state supervisor's perceptions of the performance of alternatively certified/licensed teachers' abilities in regards to classroom and laboratory, SAE, and FFA based upon the population of the community in which the alternatively certified/licensed teacher teaches.

$\mathrm{Ho}_{2}$ : No difference existed between state supervisor's perceptions of the performance of alternatively certified/licensed teachers' abilities in regards to classroom and laboratory, SAE, and FFA based upon the age of the alternatively certified/licensed teacher teaches.

\section{Summary of Findings}

The sample population for this study consisted of 23 agricultural education state supervisors in the United States (Figure 1). The state supervisors were asked to identify 
the demographic characteristics of the alternatively certified/licensed teachers working within their state. The majority of alternatively certified/licensed teachers were Caucasian males between the ages of 26 to 30 years old. The majority of the teachers were identified to be teaching within an urban area.

\section{Figure 1}

Participating State Supervisors. $(n=23)$

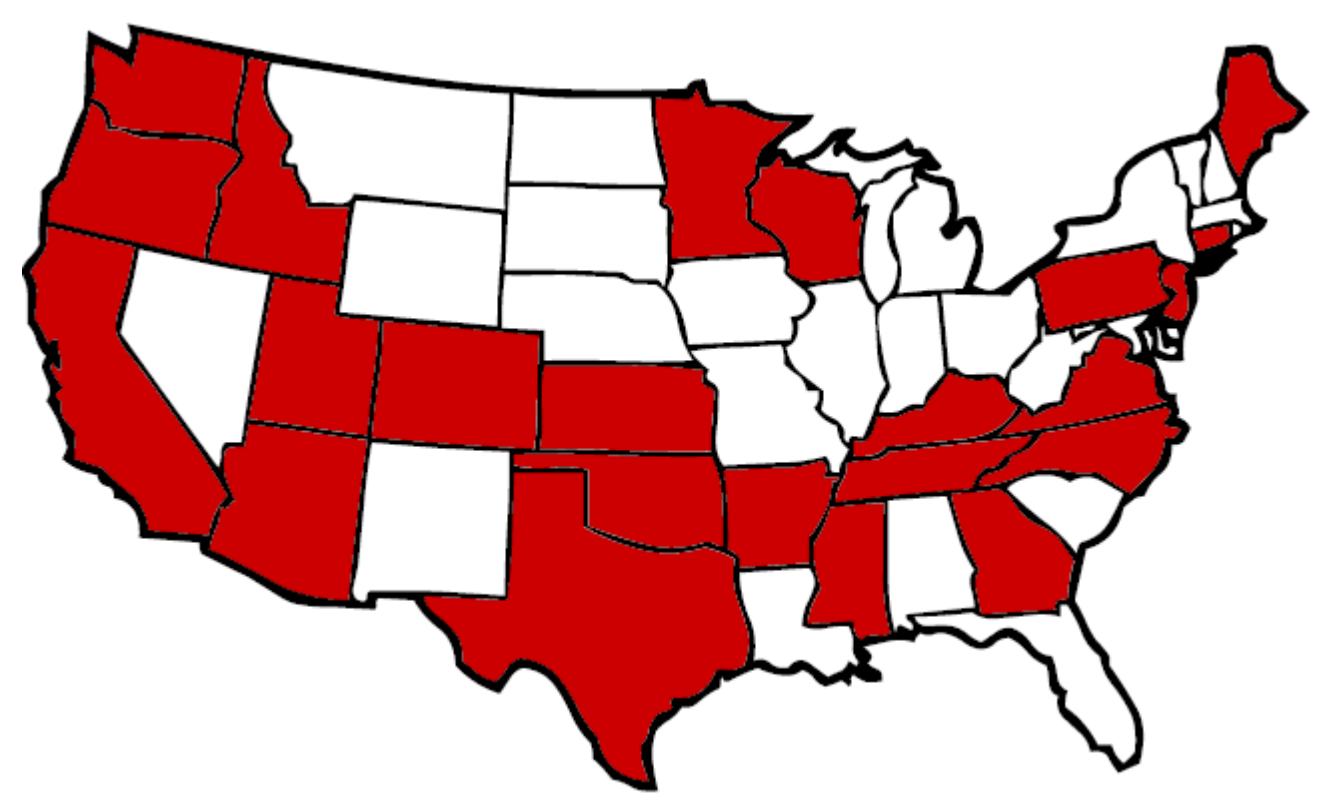

When reviewing the data compiled pertaining to the individual state requirements of alternative certification/licensure, patterns emerged. There is an average of 24 alternatively certified/licensed teachers within the 23 responding states (appendices F). The $78.3 \%$ of alternatively certified/licensed teachers have a Bachelors degree and $52.2 \%$ had experience within the agriculture industry. In regards to age, $43.5 \%$ of the alternatively certified/licensed teachers were between the ages 26 to 30 years of age. These findings are different than findings in a 2006 study conducted by Rocca and Washburn where they found that $28 \%$ of alternatively certified agriculture teachers held an advanced degree and they were on average 10 years older than traditionally certified teachers. Thirty five percent of the responding states require alternatively certified/licensed teachers to complete a formal teacher certification program within a three year period after being hired and $33 \%$ of the responding states require the alternatively certified/licensed teacher to pass the agriculture Praxis II exam (figure 2). 
Figure 2

Individual State Certification/Licensure Requirements

$\begin{array}{cccccccc}\text { Praxis } & \text { Praxis } & \text { Praxis } & \text { G.P.A } & \text { Work } & \text { Bachelors } & \text { College } & \text { Special } \\ 1 & 2 & 3 & & \text { Experience } & \text { Degree } & \text { Course } & \text { Certification } \\ & & & & & & \text { Work } & \text { Program }\end{array}$

\begin{tabular}{|c|c|c|c|c|c|c|c|c|}
\hline \multicolumn{9}{|c|}{ Required } \\
\hline Arizona & & & & & $240 \mathrm{hrs}$. & Yes & & \\
\hline \multicolumn{9}{|l|}{ Arkansas } \\
\hline California & & & & & 2 yrs. & Yes & & \\
\hline Colorado & & & & & & Yes & Yes & \\
\hline Connecticut & Yes & & & & & Yes & & \\
\hline Georgia & & & & & & Yes & Yes & \\
\hline Idaho & & & & & & & Yes & \\
\hline Kansas & & Yes & & & & & Yes & \\
\hline \multicolumn{9}{|l|}{ Kentucky } \\
\hline \multicolumn{9}{|l|}{ Minnesota } \\
\hline Mississippi & & & & & & & & $\begin{array}{c}\text { VIP } \\
\text { Program }\end{array}$ \\
\hline New Jersey & & & & & & & & $\begin{array}{c}\text { VIP } \\
\text { Program }\end{array}$ \\
\hline $\begin{array}{l}\text { North } \\
\text { Carolina }\end{array}$ & Yes & Yes & Yes & & & & Yes & \\
\hline Oklahoma & & & & & & & Yes & \\
\hline Oregon & & & & & Yes & & Yes & \\
\hline \multicolumn{9}{|l|}{ Pennsylvania } \\
\hline Tennessee & & Yes & & 2.5 & & Yes & & \\
\hline Texas & & Yes & & & & & Yes & \\
\hline Utah & & Yes & & 2.5 & & Yes & & \\
\hline Virginia & & Yes & & & & & Yes & \\
\hline Washington & & & & & 6000 hrs. & & Yes & \\
\hline Wisconsin & & & & & & & & Norda, Inc. \\
\hline
\end{tabular}


State supervisors agreed that alternatively certified/licensed teachers have high expectations for student learning and engage students in a positive learning environment while implementing higher order thinking strategies into the curriculum. State supervisors also agreed that alternatively certified/licensed teachers understand and implement $21^{\text {st }}$ century skills into the classroom and laboratory. While some components of the classroom and laboratory component were found to be acceptable, state supervisors did not feel that alternatively certified/licensed teachers were competent in regards to using appropriate teaching strategies. State supervisors also felt that alternatively certified/licensed teachers were not aware of the needs of various types of learners and that the teachers do not construct lessons that are conducive for all types of learners.

These findings align with research conducted by Danne, Beire-Smith, and Latham (2000) that many teacher education program alumni have expressed anxiety about their skills for teaching special education students in the general education classroom. General education teachers often report that they do not feel confident enough in their knowledge and skills to effectively teach students with disabilities (Hyunsoo, 2004). Alternatively certified teachers, typically, do not experience specialized course work directed to special needs students. This lack of training could have directly impacted the results of this study.

Alternatively certified/licensed teacher efficacy in regards to the SAEs was the weakest area that was identified by state supervisors. State supervisors disagreed that alternatively certified/licensed teachers understand the purpose of SAEs and that teachers engage students in SAE opportunity. Alternatively certified/licensed teachers did not require students to have an SAE and did not provided guidance through SAE visitations. This lack of SAE involvement could potentially have an impact on FFA results due to the fact that SAEs are required to advance membership in the FFA (National FFA, n.d. a).

SAEs are an important component in the total program of agriculture education and the students within the classrooms can benefit from SAEs in a variety of ways. Talbert et al. (2006) indicated that students realize several benefits from SAE participation including development of decision-making skills, including career and personal choices, improved self-confidence and human relation skills, application of knowledge learned in the classroom, knowledge of a variety of occupations and careers, 
development of time management and record-keeping skills, document of experience needed on job applications, discovery of areas of personal interest, practice of responsibility and development of independence, and development of pride through personal accomplishment. (p. 420-421) Research among enrollment, FFA membership, and SAE participation has suggested positive relationships between FFA membership and SAE participation (Retallick \& Martin, 2008). Therefore, findings in regards to FFA related items could be impacted by the students SAEs within agriculture science programs that are instructed by an alternatively certified/licensed teacher.

State supervisors agreed that alternatively certified/licensed teachers have their students attend FFA functions, such as career development events and state FFA convention, and also encourage their students to pursue chapter leadership roles. State supervisors expressed that they did not feel that alternatively certified/licensed teachers understand the purpose of FFA and that FFA membership in their chapter do not represent the demographic make-up of the school and that alternatively certified/licensed teachers do not promote the FFA to all of the students in his/her school. State supervisors also disagreed that alternatively certified/licensed teachers require their students to recite the FFA creed, which is a requirement for students to obtain their greenhand FFA degree (National FFA, n.d. a). If students do not recite the FFA creed, there is no way to pursue advanced FFA degrees, apply for proficiency awards, or pursue state or national leadership roles.

A significant difference existed between states supervisors' perceptions of teachers' efficacy in regards to classroom/laboratory $(p=.02)$ and FFA activities $(p=.05)$ when comparing the population of the community in which the alternatively certified/licensed teachers taught (rural or urban communities). Perhaps this difference can be attributed to the demographic make-up of the school's population and also the opportunities and resources that are available to the students in terms of SAEs. Also, the importance of SAEs in the total program of agriculture education is starting to diminish. Wilson and Moore (2006) found that teachers believe that principals do not reward them for having their students conduct SAE. If there is no support from a school's administration to encourage the students to have quality SAEs the motivation on the part 
of the alternatively certified/licensed teacher could decrease. Principals can support or de-emphasize the importance of SAE at their school.

\section{Recommendations}

The role of an agricultural education teacher is more complex than merely distributing information to students in the classroom. A proficient teacher must ensure that the students are engaged in the classroom, the laboratory, in their SAEs and also that the students are active participants in the National FFA Organization.

In general, teaching has a higher turnover rate than other occupations (Ingersoll, 2002). Agricultural Education has not escaped the phenomenon of teacher shortage. Camp, Broyles, and Skelton (2002) noted a shortage of agriculture teachers as early as 1965. This shortage has continued since that time (Kantrovich, 2007). Alternative teacher certification/licensure could potentially be a viable solution to the issue of an agriculture teacher shortage. In order to ensure that students are receiving a quality education, state departments of education, teacher preparation institutions, and state supervisors need to ensure a quality teacher is prepared to enter the classroom and be effective. As stated by Knight and Moore (1980), the real issue is not the source of teachers but the methods of preparation which are used to identify and prepare teachers.

This study examined state supervisors' perceptions of teacher efficacy regarding alternatively certified/licensed secondary agriculture teachers in regards to classroom and laboratory, SAEs, and FFA. Findings determined that state supervisors feel that alternatively certified/licensed teachers were performing at an acceptable level for some aspects of the classroom/laboratory and FFA components; the alternatively certified/licensed teachers were not performing up to standard in terms of SAEs.

Recommendations for future research called for a quasi-experimental research approach that would implement the same curriculum to similar classrooms using an alternatively certified/licensed teacher and a traditionally certified teacher with the same years of experience. Also, research could be conducted to determine the perceptions that students have in regards to the instructional abilities, techniques and overall classroom learning environment of an alternatively certified/licensed teacher.

A qualitative study should also be conducted where the researcher observes the alternatively certified/licensed teacher within the classroom and laboratory environment, 
during SAE visitations, and at FFA functions. The researcher would also like to see the current study replicated at a later date to include the states that did not respond $(n=22)$. It is important to try and establish a reference tool that highlights the certification/licensure of agriculture teachers across the United States. This information could potentially lead to a universal certification system for alternatively certified/licensed agriculture teachers.

With the state of the United State economy, industry professionals and agriculturists are seeking jobs as agriculture teachers. Each year, uncertified agriculture teachers are hired, largely due to a shortage of university-prepared agriculture teachers (Roberts \& Dyer, 2004). Alternative teacher certification/licensure could play a vital role in maintaining or increasing agriculture programs within high school across the United States. It is important that the teachers, who walk in to high school agriculture classrooms, are prepared to face the challenges that will be staring at them. Teachers have to be proficient in classroom and laboratory strategies and techniques, competent when dealing with SAEs, and understand the role and importance of the National FFA organization. 


\section{References}

Adcock, P. K., \& Mahlios, M. (2005). Nontraditional alternative teacher certification programs: Their purpose, design and participants. Essays in Education,15, 60-70.

Adelman, Nancy E., Michie, J., Bogart, J. (1986). An exploratory study of teacher alternative certification and retraining programs. Washington, D.C.: United States Department of Education

Ary, D., Jacobs, L.C., Razavieh, A., \& Sorenson, C. (2006). Introduction to research in education $\left(7^{\text {th }}\right.$ Ed.). California: Thomas Wadsworth.

Ashburn, Elizabeth A. (1984). Emergency teacher certification. ERIC Digest. Washington D.C.: National Institute of Education

Ashton, P.T. (1996). Improving the preparation of teachers. Educational Researcher, 25(9), 21-22

Beatty, J. C. (2004). Characteristics of West Virginia secondary agriculture educators. Unpublished Masters of Science in Agriculture and Environmental Education, West Virginia University, Morgantown, WV.

Berry, J.B. (1924). Teaching agriculture. New York: World Book.

Boyd, D., Goldhaber, D., Lankford, H., \& Wyckoff, J. (2007). The effect of certification and preparation on teacher quality. The Future of Children, Excellence in the Classroom (Spring, 2007), 17(1), 45-68

Cook, G.C., (1947). Handbook on teaching vocational agriculture. Interstate Printing Co., Danville, Ill.

Croom, D.B. (2008). The development of the integrated three-component model of agricultural education. Journal of Agricultural Education, 49(1), 109-120.

Daane, C. J., Beire-Smith, M., \& Latham, D. (2000). Administrators' and teachers' perceptions of the collaborative efforts of inclusion in the elementary grades. Education, 121, 331-338.

Dalkey, N. C., \& Helmer, O. (1963). An experimental application of the Delphi method to the use of experts. Management Science, 9(3), 458-467.

Dangel, Julie R. \& Guyton, Edith M. (Ed.). (2005). Research on alternative and nontraditional education, teacher education yearbook XIII. United States: The Association of Teacher Educators with Scarecrow Education.

Darling-Hammond, L. (1990). Teaching and knowledge: Policy issues posed by alternate certification for teachers. Peabody Journal of Education, 67(3), 123-154. 
Darling-Hammond, L., \& Cobb, V.L. (1996). The changing context of teacher education. In F. Murray (Ed.), The teacher educator's handbook: Building a knowledge base for the preparation of teachers (pp. 14-62). San Francisco: Jossey-Bass.

Dillman, D.A. (2000). Mail and internet surveys: The tailored design method ( $7^{\text {th }}$ Ed.). New York: John Wiley and Sons, Inc.

Duncan, D.W., \& Ricketts, J.C. (2008). Total program efficacy: a comparison of traditionally and alternatively certified agriculture teachers. Journal of Agricultural Education, 49(4), 38-46.

Everitt, A. (2001). Cicero: The Life and Times of Rome's greatest politician. Great Britian: John Murray (Publishers) Ltd.

Feistritzer, C.E., \& Chester, D.T. (1998). Alternative teacher certification: A state by state analysis. Washington, DC: National Center for Education Information.

Fleet, Bill. (2007, October). Looking to the Future. FFA Advisors Making a Difference, 15(88), p. 1.

Gerlock, D. E. (1964). An analysis of administrators' evaluations of selected professionally and provisionally certified secondary school teachers. Unpublished Doctor of Education, Florida State University, Tallahassee, FL.

Hamlin, H.M. (1949). Agricultural education in community schools. Interstate Printing Co., Danville, Ill.

Hamlin, H.M. (1962). Public school education in agriculture. Danville, IL: Interstate.

Hawley, Willis D. (1985). Notes on the Teacher Shortage Issue: Directions for Federal, State, and Local Policies. Tennessee: Vanderbilt University

Hyunsoo, K. (2004). Kansas general education teachers' attitudes toward inclusion, perceptions about teacher education programs, and knowledge about special education content. Unpublished doctoral dissertation, University of Kansas,Lawrence.

Ingersoll, R. (2002). The teacher shortage: A case of wrong diagnosis and wrong prescription. NASSP Bulletin, 86, 16-31.

Knight, James \& Moore, Gary E. (1980). Special feature- debate the issues. The Journal of American Associations of Teacher Educators in Agriculture, XXI (2), 2-10.

Knobloch, N. A., \& Whittington, M. S. (2002). Novice teachers' perception of support, teacher preparation quality, and student teaching experience related to teacher efficacy. Journal of Vocational Education Research, 27(3), 331-341. 
Lackzo-Kerr, L. \& Berliner, D. C. (2002). The effectiveness of "Teach for America" and other under-certified teachers on student academic achievement: A case of harmful public policy. Educational Policy Analysis Archive, 10(37). Retrieved from www.epaa.asu.edu/epaa/v10n37

Miller, J. W., McKenna, M. C., \& McKenna, B. A. (1998). Nontraditional teacher preparation: A comparison of alternatively and traditionally prepared teachers. Journal of Teacher Education, 49(3), 165-176.

Miller, W.W.,Kahler, A.A., \& Rheault, K. (1989). Profile of effective vocational agriculture teacher. Journal of Agriculture Education, 30(2) 33-40.

Moore, G.E. (1988). The forgotten leader in agricultural education: Rufus W. Stimson. Journal of the American Association of Teacher Educators in Agriculture, 29(3), 50-58.

National Association of Agriculture Educators, (n.d.). NAAE teacher mentor award application. Retrieved September 20, 2007, from http://www.naae.org/awards/applications/2007apps/

National FFA Organization. (n.d. a) FFA History. Retrieved September 6, 2009, from http://www.ffa.org/index.cfm?method=c_about.history

National FFA Organization. (n.d. b) FFA History. Retrieved September 6, 2009, from http://www.ffa.org/index.cfm?method=c_aged.Chapters\#poa

National FFA Organization. (n.d. c) FFA History. Retrieved September 6, 2009, from https://www.ffa.org/about/whoweare/Pages/MissionandMotto.aspx

National FFA Organization. (n.d. d) FFA History. Retrieved September 6, 2009, from https://www.ffa.org/programs/awards/cde/Pages/default.aspx

National Commission on Teaching \& America's Future. (1996). What Matters Most: Teaching for America's Future. New York: New York.

Phipps, L.J. \& Cook, G.C. (1952). A handbook on teaching vocational agriculture. Interstate Printing Co., Danville, Ill.

Phipps, L.J., Osborne, E.W., Dyer, J.E., and Ball, A.L. (2008). Handbook on agricultural education in public schools. Thomson Learning, Inc.: Clifton Park, NY.

Reichardt, R. (2002). Alternative teacher education: Trends and implications in policies and practices. Aurora, CO: Mid-Continent Research for Education and Learning, Boulder, CO: Western Interstate Commission for Higher Education. 
Retallick, M. S., \& Martin, R. A. (2008). Fifteen year enrollment trends related to the three components of comprehensive agricultural education programs. Journal of Agricultural Education, 49(1), 28 - 38. doi:10.5032/jae.2008.01028

Rocca, S.J., \& Washburn, S.G. (2006). Comparison of teacher efficacy among traditionally and alternatively certified agriculture teachers. Journal of Agricultural Education, 47(3), 58-69.

Roberts, T. G., \& Dyer, J. E. (2004). Inservice needs of traditionally and alternatively certified agriculture teachers. Journal of Agricultural Education, 45(4), 57-70. doi: $10.5032 /$ jae.2004.04057

Shen, J. (1997). Has the alternative certification policy materialized its promise? A comparison between traditionally and alternatively certified teachers in public schools. Educational Evaluation and Policy Analysis, 19(3), 276-283.

Shoho, A. R., \& Martin, N. K. (1999). A comparison of alienation among alternatively and traditionally certified teachers. Paper presented at the meeting of the American Educational Research Association, Montreal, Quebec, Canada.

Stoddart, T., \& Floden, R. E. (1995). Traditional and alternate routes to teacher certification: Issues, assumptions, and misconceptions. Issue Paper 25-2, \#488241034, from the National Center for Research on Teacher Learning, ERIC Document, ED 383697. .

Talbert, B.A., Vaughn, R., Croom, D.B. (2006). Foundations of agricultural education. Caitlyn, IL: Professional Educators Publications.

Teach for America. (2011, January). Retrieved from http://www.teachforamerica.org/

Turley, S. \& Nakai, K. (2000). Two Routes to Certification: What Do Student Teachers Think? Journal of Teacher Education, 51(2), 122-134.

U.S. Department of Education. (2002, June). Meeting the highly qualified teachers challenge: The Secretary's annual report on teacher quality. Washington, DC: Author.

Walsh, K., Jacobs, S., \& Thomas B. Fordham Foundation, W. C. (2007). Alternative Certification Isn't Alternative. Thomas B. Fordham Institute, Retrieved from EBSCOhost.

Wilson, E. B., \& Moore, G. E. (2006). Walking the talk: Factors related to the motivation of teachers to conduct the SAE component of the agricultural education program. Proceedings of the Southern Region Conference of the American Association for Agricultural Education. Orlando, FL. 
Zirkle, C. J., Martin, L., McCaslin, N. L., \& National Research Center for Career and Technical, E. (2007). Study of State Certification/Licensure Requirements for Secondary Career and Technical Education Teachers. National Research Center for Career and Technical Education, Retrieved from EBSCOhost. 
APPENDICIES 
APPENDIX A

Phase I Questionnaire 


\section{Use and satisfaction of alternative certification in Agricultural Education as perceived by teacher educators in the United States.}

Directions: Please write your responses below the following questions.

1. How many agricultural education teachers are there in your state?

2. What is your definition of alternative teacher certification/licensure?

3. Does your state/institution offer alternative certification/licensure for agricultural education and if so, how long has it been offered?

4. How many individuals are alternatively certified/licensed at your institution per year? 
5. What is the general demographic background of the alternative certification/licensure candidates over the past two years? (i.e. Educational background, Age, Industry Background)

\begin{tabular}{|c|c|c|}
\hline Degree & Average Age & Industry Background \\
\hline Associates & O $25-30$ & Agribusiness \\
\hline O Bachelors & O $31-35$ & O Agronomy \\
\hline O Masters & O $36-40$ & O Ag. Engineering \\
\hline \multirow[t]{6}{*}{ Other } & ○ 41-45 & O Animal Science \\
\hline & O 46 and Above & O Forestry \\
\hline & & $\begin{array}{l}\text { Horticulture / } \\
\text { Floriculture }\end{array}$ \\
\hline & & ○ Natural Resources \\
\hline & & O Poultry \\
\hline & & Other (Please List) \\
\hline
\end{tabular}

6. What percent of alternative certification/licensure candidates took agriculture classes in high school?

7. What are the educational requirements / standards of alternative certification/licensure candidates? (i.e. Number of courses required in Agriculture and Pedagological courses and total course hours)

8. Are alternative certification candidates certified to teach all aspects of agriculture education or just a specific discipline? (i.e. Horticulture, Agribusiness, Agriculture Mechanics, Animal Science) 
9. What are three positive aspects of alternative certification/licensure?

10. What are three negative aspects of alternative certification/licensure?

11. If you do not offer alternative certification/licensure, would you like to offer it and if so why?

12. If you do not offer alternative certification/licensure, what is your reasoning for not offering it? 
APPENDIX B

State Phone Call Script 
Good Morning my name is and I am a graduate student at West Virginia University. I am currently conducting a study to examine state supervisors' perceptions of teacher efficacy on traditionally and alternatively certified/licensed secondary agriculture teachers.

Would you be willing to answer a few questions about agriculture teacher certification in your state? Thank you.

1. Do you offer alternative teacher certification in your state?

\section{If they do ask...}

1. How long have you been offering alternative certification?

2. Would you be willing to complete a brief online survey to address some questions that we have about alternative certification? It will only take 10 minutes of your time.

3. If they say yes tell them that they will be receiving an email initiation sometime today and the subject line will read WVU Research Survey.

\section{If they don't offer it ask...}

1. Do you feel that your state would benefit from offering alternative certification?

2. If someone has a degree in animal science or horticulture and they want to teach in a high school, what means do they have to pursue to become certified to teach?

Thank you for your time and your participation. It was nice talking with you. Have a nice day. 
APPENDIX C

Cover Letter 
To: [Email]

From: "sgartin@wvu.edu via surveymonkey.com" < member@surveymonkey.com>

Subject: West Virginia University Research Study

Body: Dear State Supervisor:

I am Joshua Rice, a graduate student in Agricultural and Extension Education at West Virginia University. Under the direction of my advisor, Dr. Stacy A. Gartin, I am conducting a study to examine state supervisors' perceptions of teacher efficacy on traditionally and alternatively certified/licensed secondary agriculture teachers. I would like to once again take this opportunity to once again ask you to be a participant in this research study. The results will provide insight to agricultural education teachers, universities, and state supervisors involved with the preparation of agricultural educators.

Participation in this research study is voluntary, and will take approximately ten minutes of time. Please follow the following link to access and complete the survey.

http://www.surveymonkey.com/s.aspx

All responses will be held as confidential as possible. Survey results will be reported in a summary format and individual responses will not be identifiable. Please answer all questions honestly. There is no penalty and services will not be withheld if you choose not to participate.

You will find the survey accompanying this email. Please place you responses below the questions. We thank you in advance for your participation in the study. If you have questions please contact Joshua at 304-293-5650 or Dr. Gartin at 304-293-5500.

Thanks for your participation!

Sincerely,

Joshua E. Rice

Graduate Student
Stacy A, Gartin, Ph.D.

Professor and Chairman 
APPENDIX D

Phase II Questionnaire 


\section{Teacher Certification}

Does your state offer a means of alternative teacher certification/licensure for agricultural education teachers?

$$
\begin{aligned}
& \text { Yes } \\
& \text { No }
\end{aligned}
$$

If you answered yes to the previous question please proceed to page two. If your state does not offer alternative certification/licensure, I would IIke to thank you for your time. 


\section{Teacher Certification}

\section{Classroom \& Lab}

The altematively certified/licensed agriculture educator...

Writes measurable objectives.

Strongly Disagree $\quad$ DIsagree Agree Strongly Agree

Uses an interest approach to attract students' attention.
Strongly Disagree
Disagree
Agree
Strongly Agree

Has high expectations for student learning.

Strongly Disagree

Disagree

Agree

Strongly Agree

Uses appropriate teaching strategies.

Strongly Disagree

Disagree

Agree

Strongly Agree

Implements higher order thinking into lessons.

Strongly Disagree

Disagree

Agree

Strongly Agree

Engages students in experiential learning.

Strongly Disagree

Disagree

Agree

Strongly Agree

Understands and implements technology (21st Century Skills) in the classroom and labs .

Strongly Disagree

Disagree

Can effectively construct lesson plans.

Strongly Dlsagree

Dlsagree

Agree

Strongly Agree

Is aware of the various needs of diverse groups of learners at different ability levels.

Strongly Disagree

Disagree

Agree

Strongly Agree

Constructs lessons that are conducive to learning for all types of learners (Audible, Visual, \& Kinesthetic). 


\section{Teacher Certification}

Maintains a positive classroom learning environment.

Strongly Disagree

Disagree

Agree

Strongly Agree

Works with other teachers to teach across the curriculum.

Strongly Disagree

Disagree

Agree

Strongly Agree

Implements current events and new information into the curriculum.

Strongly Disagree

Disagree

Agree

Strongly Agree

Uses the laboratories as an extension of the educational concepts learned in the classroom.

Strongly Disagree

Disagree

Agree

Strongly Agree

Varies the teaching strategies that he/she uses.

Strongly Disagree

Disagree

Agree

Strongly Agree

Uses appropriate assessment to measure student learning. 


\section{Teacher Certification}

\section{Supervised Agricultural Experience Program}

The altematively certified/licensed agriculture educator...

All students have a supervised agricultural experience program (SAE).
strongly Disagree
Disagree
Agree
Strongly Agree

Explores SAE opportunities with first year students.

Strongly DIsagree

Disagree

Agree

Strongly Agree

Promotes the scope and growth of SAE.

Strongly Dlsagree

Disagree

Agree

Strongly Agree

Primarily supervises SAEs during summer months.

Strongly Disagree

Disagree

Agree

Strongly Agree

Helps students find employment opportunities for SAEs.

Strongly DIsagree

Disagree

Agree

Strongly Agree

Submits state degree applications for state FFA degrees.

Strongly Disagree

Disagree

Agree

Strongly Agree

Supervises each student's SAE at least four times a year.

Strongly DIsagree

Disagree

Agree

Strongly Agree

Involves students in profitable SAEs.

Strongly Dlsagree

Disagree

Agree

Strongly Agree

Promotes entrepreneurship SAEs for students with off-farm agricultural interests.

Strongly Dlsagree

Disagree

Agree

Strongly Agree

Involves students in challenging SAEs. 


\section{Teacher Certification}

Students apply for proficiency awards each year.

Strongly Disagree

Disagree

Agree

Strongly Agree

Students submit accurate and complete records of their SAE.

Strongly Disagree

Disagree

Agree

Strongly Agree

Promotes SAE opportunities in entrepreneurship.

Strongly Disagree

Disagree

Agree

Strongly Agree

Promotes SAE opportunities in placement settings.

Strongly Disagree

Disagree

Agree

Strongly Agree

Promotes SAE opportunities in research.

Strongly Disagree

Disagree

Agree

Strongly Agree

Promotes SAE opportunities in exploratory settings.

Strongly Disagree

Disagree

Agree

Strongly Agree 


\section{Teacher Certification}

\section{National FFA Organization}

The altematively certified/licensed agriculture educator...

FFA membership reflects the demographic make-up of the school.

strongly Disagree

Disagree

Agree

Strongly Agree

Understands the purpose of the FFA.

Strongly Disagree

Disagree

Agree

Strongly Agree

Holds regular scheduled FFA meetings.

Strongly Disagree

Disagree

Agree

Strongly Agree

Uses community resources that are available.

Strongly Disagree

Disagree

Agree

Strongly Agree

Students participate in career development events.

strongly Disagree

Disagree

Agree

Strongly Agree

Holds an annual parent/member banquet.

Strongly Disagree

Disagree

Agree

Strongly Agree

Students attend state FFA convention.

Strongly Disagree

Disagree

Agree

Strongly Agree

Students attend national FFA convention.

Strongly Disagree

Disagree

Agree

Strongly Agree

Students pursue a FFA chapter leadership role.

Strongly Disagree

Disagree

Agree

Strongly Agree

Students pursue a FFA state leadership role.

Strongly Disagree

Disagree

Agree

Strongly Agree 


\section{Teacher Certification}

Promotes the FFA to all students in his/her school.

Strongly Dlsagree

Disagree

Agree

Strongly Agree

Requires students to recite the FFA creed.

Strongly Disagree

Disagree

Agree

Strongly Agree

Encourages students to participate in public speaking.

Strongly DIsagree

Disagree

Agree

Strongly Agree

Students engage in state FFA leadership activities.

Strongly Disagree

Disagree

Agree

Strongly Agree

Effectively advises the FFA chapter.

Strongly Disagree

Disagree

Agree

Strongly Agree

Assists with fund raising for chapter activities.

Strongly Disagree

Disagree

Agree

Strongly Agree 


\section{Teacher Certification}

\section{Demographic Information}

Please list below the requirements to complete the Alternative Certification/licensure program in your state...

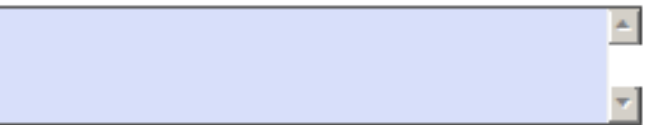

How many Alternatively Certified teachers in your state have completed the certification program?

FIII In the correct number

here.

The majority of alternatively certified/licensed teachers in my state are...

Male

Female

The average age of alternatively certified/licensed teachers when they begin teaching in my state is...
21-25 Years
26-30 Years
$31-35$ Years
36-40 Years
41 Years and Over

The ethnicity of the majority of alternatively certified/licensed teachers in my state is...
Caucasian
African American/Black
Hispanic/Latino
Aslan
Mlddle Eastern
Pacifle Islander
Nattive American/Alaskan
Other 


\section{Teacher Certification}

The background/prior experience of alternatively certified licensed agricultural education teachers in my state are...

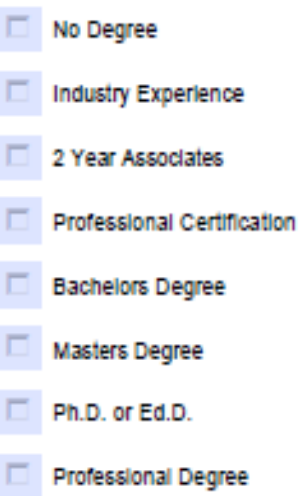

The program of the Alternatively Certified/licensed teacher is located in which of the following demographic areas.

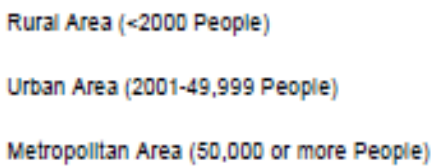


APPENDIX E

Follow-Up Cover Letter 


\section{To: [Email]}

\section{From: "sgartin@wvu.edu via surveymonkey.com"}

\section{Subject: WVU Research Study Reminder}

\section{Body: Dear State Supervisor:}

I am Joshua Rice, a graduate student in Agricultural and Extension Education at West Virginia University. Under the direction of my advisor, Dr. Stacy A. Gartin, I am conducting a study to examine state supervisors' perceptions of teacher efficacy on traditionally and alternatively certified/licensed secondary agriculture teachers. I would like to take this time to ask you to please participate in this study so a more comprehensive understanding of certification/licensure measures can be compiled for teacher preparation in agricultural education.

The results will provide insight to agricultural education teachers, universities, and state supervisors involved with the preparation of agricultural educators.

Participation in this research study is voluntary, and will take approximately ten minutes of time. Please follow the following link to access and complete the survey.

http://www.surveymonkey.com/s.aspx

All responses will be held as confidential as possible. Survey results will be reported in a summary format and individual responses will not be identifiable. Please answer all questions honestly. There is no penalty and services will not be withheld if you choose not to participate.

You will find the survey accompanying this email. Please place you responses below the questions. We thank you in advance for your participation in the study. If you have questions please contact Josh at 304293-5650 or Dr. Gartin at 304-293-5500. 
Thank you again for your times and participation!

Sincerely,

Joshua E. Rice

Stacy A, Gartin, Ph.D.

Graduate Student

Professor and Chairman 


\section{APPENDIX F}

Individual State Certification/Licensure Information 
Requirements and Characteristics of Alternatively

Certified/Licensed Teachers in Arizona

Requirements for

Alternative

Certification/Licensure
Must have a Bachelor's degree or related science certification. Must have had 240 hours of verified work experience in an Agriscience related field or an advanced degree in Agriscience.

72

Number of Alternatively

Certified/Licensed

Teachers

Sex

Age

Race

Background

Population of the school district in which they teach.
Female

$21-25$

Caucasian

Industry

Urban Area (2001-49,999 People) 
Requirements and Characteristics of Alternatively

Certified/Licensed Teachers in Arkansas

Requirements for NA

Alternative

Certification/Licensure

Number of Alternatively

40

Certified/Licensed

Teachers

Sex

Male

Age

$31-35$

Race

Caucasian

Background

Bachelors Degree

Population of the school

Rural Area (<2000 People)

district in which they

teach. 
Requirements and Characteristics of Alternatively

Certified/Licensed Teachers in California

Requirements for

Alternative

Certification/Licensure

Number of Alternatively

Certified/Licensed

Teachers

Sex

Age

Race

Background

Population of the school district in which they teach.
Bachelors degree, 2 years of recent industry experience or teaching certificate in any area of study counting for 1 year of experience

12

Male

26-30

Caucasian

Industry experience or professional teaching certificate

Urban Area (2001-49,999 People) 
Requirements and Characteristics of Alternatively

Certified/Licensed Teachers in Colorado

Requirements for

Alternative

Certification/Licensure
Bachelors degree Agriculture that includes 24 credit hours of course work in four of Colorado's six agriculture pathways of completion. Six of the credit hours must include the instruction and philosophy of career and technical education, management of content standards and objective and course work in laboratory safety and management.

Number of Alternatively

15

Certified/Licensed

Teachers

Sex

Male

Age

26-30

Race

Caucasian

Background

Bachelors Degree

Population of the school district in which they teach. 
Requirements and Characteristics of Alternatively

Certified/Licensed Teachers in Connecticut

Requirements for

Alternative

Certification/Licensure

Number of Alternatively

Certified/Licensed

Teachers

Sex

Age

Race

Background

Population of the school district in which they teach.
Bachelors degree with a major in Agriculture. They must also attend alternate route to certification classes and pass the Praxis 1 exam.

4

Male

$26-30$

Caucasian

Bachelors Degree and industry experience in agriculture

Urban Area (2001-49,999 People) 
Requirements and Characteristics of Alternatively

Certified/Licensed Teachers in Georgia

Requirements for

Alternative

Certification/Licensure

Number of Alternatively 5

Certified/Licensed

Teachers

Sex

Age

Race

Background

Population of the school district in which they teach. 4-year degree in agriculture related field and complete the required training sessions.

Male

$36-40$

Caucasian

Bachelors Degree and industry experience in agriculture

Rural Area (<2000 People) 
Requirements and Characteristics of Alternatively

Certified/Licensed Teachers in Idaho

\begin{tabular}{|c|c|}
\hline $\begin{array}{l}\text { Requirements for } \\
\text { Alternative } \\
\text { Certification/Licensure }\end{array}$ & $\begin{array}{l}\text { Receives a certificate that is valid for three years. Within } \\
\text { the first } 18 \text { months of certification, the holder must: } \\
\text { complete either a pre-service workshop sponsored by the } \\
\text { State Division of Professional-Technical Education or an } \\
\text { approved course in professional-technical methods/student } \\
\text { assessment. Alternatively certified/licensed teachers must } \\
\text { complete a new-teacher induction workshop at the state or } \\
\text { district level and file a Professional Development Plan with } \\
\text { the State Division of Professional-Technical Education. } \\
\text { Within the three year period of the Limited Occupational } \\
\text { Specialist Certificate, the instructor must satisfactorily } \\
\text { complete coursework which includes competencies in four } \\
\text { of the following: Principles/Foundations of Occupational } \\
\text { Education; Career Pathways and Guidance; Analysis, } \\
\text { Integration and Curriculum Development; Measurement } \\
\text { and Evaluation; and Methods of Teaching Occupational } \\
\text { Education. }\end{array}$ \\
\hline $\begin{array}{l}\text { Number of Alternatively } \\
\text { Certified/Licensed } \\
\text { Teachers }\end{array}$ & 10 \\
\hline Sex & Male \\
\hline Age & $36-40$ \\
\hline Race & Caucasian \\
\hline Background & Industry experience in agriculture \\
\hline $\begin{array}{l}\text { Population of the school } \\
\text { district in which they } \\
\text { teach. }\end{array}$ & Rural Area (<2000 People) \\
\hline
\end{tabular}


Requirements and Characteristics of Alternatively

Certified/Licensed Teachers in Kansas

Requirements for

Alternative

Certification/Licensure
Individuals seeking alternative certification/licensure who do not have a teaching license and come in from business and industry must complete the required course hours and obtain a certified license. While completing the hours they will be placed on a probationary license. If they are a certified educator but in another related field such as science they will need to take the Praxis II test for agriculture.

Number of Alternatively

9

Certified/Licensed

Teachers

Sex

Male

Age

41 year and older

Race

Caucasian

Background

Bachelors Degree and industry experience in agriculture

Population of the school district in which they

Rural Area (<2000 People) teach. 
Requirements and Characteristics of Alternatively

Certified/Licensed Teachers in Kentucky

Requirements for

Alternative

Certification/Licensure
Option 1: Exceptional Work Experience Certification

Option 2: Local District Training Program Certification

Option 3: College Faculty Certification

Option 4: Adjunct Instructor Certification

Option 5: Veterans of the Armed forces

Option 6: University-Based Alternative Route to

Certification

Option 7: Institute Alternative Route to Certification

Option 8: Teach for America (TFA) Alternative Route to

Certification

Number of Alternatively 1

Certified/Licensed

Teachers

Sex

Age

Race

Background

Population of the school district in which they teach.
Female

$36-40$

Caucasian

Masters Degree

Urban Area (2001-49,999 People) 
Requirements and Characteristics of Alternatively

Certified/Licensed Teachers in Minnesota

Requirements for

Alternative

Certification/Licensure

Number of Alternatively

Certified/Licensed

Teachers

Sex

Age

Race

Background

Population of the school district in which they teach.
Can obtain a community expert status that is a one year license for districts not able to find a licensed teacher and a limited license renewable annually up to 3 times.

0

NA

$31-35$

Caucasian

Bachelors Degree

Rural Area (<2000 People) 
Requirements and Characteristics of Alternatively

Certified/Licensed Teachers in Mississippi.

Requirements for

Alternative

Certification/Licensure

Number of Alternatively

Certified/Licensed

Teachers

Sex

Age

Race

Background

Population of the school district in which they teach.
Must complete a VIP program and complete course work in best teaching practices.

9

Male

26-30

Caucasian \& Middle Eastern American

Bachelors Degree

Rural Area (<2000 People) 
Requirements and Characteristics of Alternatively

Certified/Licensed Teachers in New Jersey.

Requirements for

Alternative

Certification/Licensure

Number of Alternatively

Certified/Licensed

Teachers

Sex

Age

Race

Background

Population of the school district in which they teach.
Must complete a VIP program and complete course work in best teaching practices.

15

Male

26-30

Caucasian

2 Year Associates Degree, Bachelors Degree, Industry experience in agriculture.

Urban Area (2001-49,999 People) 
Requirements and Characteristics of Alternatively

Certified/Licensed Teachers in North Carolina.

Requirements for
Alternative
Certification/Licensure $\quad \begin{aligned} & \text { A person who holds a lateral entry license shall } \\ & \text { complete a program that includes the following } \\ & \text { components: } \\ & \text { (1) Completion of an approved teacher education } \\ & \text { program in the area of licensure at a college or } \\ & \text { university or completion of a program of study } \\ & \text { outlined by the Regional Alternative Licensing } \\ & \text { Centers; Prescribed academic content } \\ & \text { coursework that is available through community } \\ & \text { colleges may be used to satisfy licensure } \\ & \text { requirements. General pedagogy competencies } \\ & \text { can be satisfied as follows. } \\ & \text { (2) Attaining passing score on appropriate PRAXIS } \\ & \text { subject exam(s) during the first three school } \\ & \text { years of holding the lateral entry license if the } \\ & \text { exam(s) was/were not the basis of qualifying for } \\ & \text { the license; } \\ & \text { (3) Completion of a staff development program that } \\ & \text { includes a two-week training course prior to } \\ & \text { beginning the work assignment; } \\ & \text { (4) Completion of a cumulative of six semester } \\ & \text { hours of course work in the approved program } \\ & \text { each school year; } \\ & \text { (5) Successful completion of at least a three-year } \\ & \text { initial licensure program in the lateral entry } \\ & \text { license area; } \\ & \text { (6) Completion of all above requirements within } 3 \\ & \text { years of becoming eligible for a lateral entry } \\ & \text { license for clear licensure. }\end{aligned}$

Number of Alternatively $\quad 50$

Certified/Licensed

Teachers

\begin{tabular}{ll} 
Sex & Male \\
Age & $36-40$ \\
Race & Caucasian \\
Background & Bachelors Degree \\
$\begin{array}{ll}\text { Population of the school } \\
\text { district in which they } \\
\text { teach. }\end{array}$ & Metropolitan Area (50,000 or more People) \\
\hline
\end{tabular} 
Requirements and Characteristics of Alternatively

Certified/Licensed Teachers in Oklahoma.

Requirements for

Alternative

Certification/Licensure
Must attend all new teacher workshops and complete 9 of 12 college credit hours in three years. They also have the option of attending Southern Region Educational Board training.

Number of Alternatively NA

Certified/Licensed

Teachers

Sex

NA

Age

$21-25$

Race

Background

Population of the school district in which they teach.

\section{Caucasian}

Bachelors Degree

Urban Area (2001-49,999 People) 
Requirements and Characteristics of Alternatively

Certified/Licensed Teachers in Oregon.

Requirements for

Alternative

Certification/Licensure
Industry experience and planned course work to be completed in 3 years, Appropriate Education background as determined by the State $\mathrm{Ag}$ Ed Specialist and there has to be a need at the local school district.

11

Number of Alternatively

Certified/Licensed

Teachers

Sex

Male

Age

26-35

Race

Background

Population of the school district in which they teach.

\section{Caucasian}

Bachelors Degree and Industry experience in agriculture.

Rural Area $(<2000$ People) 
Requirements and Characteristics of Alternatively

Certified/Licensed Teachers in Pennsylvania.

Requirements for NA

Alternative

Certification/Licensure

Number of Alternatively $\quad 4$

Certified/Licensed

Teachers

Sex

Male

Age

26-30

Race

Caucasian

Background

Professional certificates, a Bachelors degree, a professional degree and industry experience in agriculture.

Population of the school Urban Area (2001-49,999 People) district in which they teach. 
Requirements and Characteristics of Alternatively

Certified/Licensed Teachers in Tennessee.

Requirements for

Alternative

Certification/Licensure
Bachelor of Science Degree in Agriculture with at least a 2.5 GPA and Pass the Praxis II exam in Agriculture. If the individual holds a current professional license they must pass the agriculture Praxis II.

Number of Alternatively

42

Certified/Licensed

Teachers

Sex

Male

Age

26-30

Race

Caucasian

Background

Bachelors Degree

Population of the school district in which they teach.

Rural Area (<2000 People) 
Requirements and Characteristics of Alternatively

Certified/Licensed Teachers in Texas.

Requirements for

Alternative

Certification/Licensure

Number of Alternatively

Certified/Licensed

Teachers

Sex

Age

Race

Background

Population of the school district in which they teach.
Complete an educator preparation program and pass Texas state teacher general and subject area exams.

NA

Male

$31-35$

Caucasian

Bachelors Degree

Urban Area (2001-49,999 People) 
Requirements and Characteristics of Alternatively

Certified/Licensed Teachers in Utah.

Requirements for

Alternative

Certification/Licensure
Bachelor of Science Degree in Agriculture with at least a 2.5 GPA and Pass the Praxis II exam in Agriculture. If the individual holds a current professional license they must pass the agriculture Praxis II.

Number of Alternatively $\quad 18$

Certified/Licensed

Teachers

Sex

Male

Age

$36-40$

Race

Caucasian

Background

Bachelors Degree and industry experience in agriculture.

Population of the school district in which they

Urban Area (2001-49,999 People) teach. 
Requirements and Characteristics of Alternatively

Certified/Licensed Teachers in Virginia.

Requirements for

Alternative

Certification/Licensure
Complete 39 hours of technical agriculture classes.

Complete courses in required areas in agriculture. Complete 15 hours of professional education courses. Pass Praxis II.

Number of Alternatively

20

Certified/Licensed

Teachers

Sex

Male

Age

$21-25$

Race

Caucasian

Background

Bachelors Degree and industry experience in agriculture.

Population of the school district in which they teach. 
Requirements and Characteristics of Alternatively

Certified/Licensed Teachers in Washington.

Requirements for

Alternative

Certification/Licensure
Obtain a career and technical education certification in an area they have been employed in for a minimum of 6000 hours. Certificate is limited to that area of employment/expertise.

100

Number of Alternatively

Certified/Licensed

Teachers

Sex

Age

Race

Background

Population of the school district in which they teach.
Female

$36-40$

Caucasian

No degree, a Bachelors degree or industry experience in agriculture.

Urban Area (2001-49,999 People) 
Requirements and Characteristics of Alternatively

Certified/Licensed Teachers in Wisconsin.

Requirements for

Alternative

Certification/Licensure

Number of Alternatively

Certified/Licensed

Teachers

Sex

Age

Race

Background

Population of the school district in which they teach.
Teachers obtain certification through a company called Norda, Inc.

0

NA

NA

NA

Bachelors degree

Rural Area ( $<2000$ People) 


\title{
Joshua E. Rice
}

\author{
Email: Joshuarice85@gmail.com \\ 9 Melrob Court Apt. 1 \\ Annapolis, MD 21403 \\ Phone: 1-410-212-7860
}

\section{Education:}

West Virginia University, Morgantown, WV 26506.

Doctorate of Philosophy in Resource Management and Sustainable Development with a focus in Human and Community Development.

Graduation Date: May 13, 2012

Course work specializing in: Curriculum evaluation, theories and models of research, higher education administration, on-line course construction and evaluation, and advanced teaching strategies.

Dissertation Title: State supervisors' perceptions of teacher efficacy regarding alternatively certified/licensed secondary agriculture teachers.

West Virginia University, Morgantown, WV 26506.

Earned a Masters Degree in Agriculture with a major in Agriculture, Natural Resources and Design in August 2010. Completed teacher certification in Agricultural Education in the spring of 2009.

Course work specializing in: teaching strategies, classroom assessment, foundations of learning, plant and soil science, communications, leadership, program and curriculum development.

West Virginia University, Morgantown, WV 26506.

Earned a Bachelor of Science in Agriculture with a major in Animal and Veterinary Sciences with minors in Equine Management and Sociology in May of 2007.

\section{Referred Journal Articles:}

Rice, J.E., LaVergne, D.D., \& Gartin, S.A. (2012). Agricultural teacher perceptions of school components as motivational factors to continue teaching and demotivational factors to discontinue teaching. Journal of Career and Technical Education, 26(2), 105-115.

\section{Research (Staff) Studies:}

Rice, J.E., Gartin, S.A., LaVergne, D.D. (2011). Exploring the correlation between agricultural education program success and the role of the school administrators. West Virginia University. Submitted and under review to the Journal of Agricultural Education.

Rice, J.E., Gartin, S.A., LaVergne, D.D. (2011). Agricultural mechanics competencies in high school agricultural education students and state content standard objectives. West Virginia University. Submitted and under review to the Journal of Agricultural Education.

Kneer, A.M., Rice, J.E., Gartin, S.A., (2011). Facebook as an educational tool in an agricultural communications course. West Virginia University. Submitted and under review to the Journal of Distance Education. 


\section{Refereed Regional Research Posters:}

(Published in Proceedings of the North Central Research Conference in Agricultural Education.)

Rice, J.E., Gartin, S.A., LaVergne, D. (2011). Assessing the agricultural mechanic competencies of former high school agricultural education students. Presented at the $9^{\text {th }}$ Annual North Central Region American Association of Agricultural Educators Research Conference, University Park, Pennsylvania.

Rice, J.E., Gartin, S.A., LaVergne, D. (2011). Examining the principal's role in continued growth and success of high school agriculture education teachers. Presented at the $9^{\text {th }}$ Annual North Central Region American Association of Agricultural Educators Research Conference, University Park, Pennsylvania.

Rice, J.E., Gartin, S.A., LaVergne, D. (2011). Perceptions of high school principals in regarding supervised agriculture experiences. Presented at the $9^{\text {th }}$ Annual North Central Region American Association of Agricultural Educators Research Conference, University Park, Pennsylvania.

Rice, J.E., Gartin, S.A., LaVergne, D. (2011). Examining the factors associated with continued motivation to be a highly effective teacher regarding classroom instruction and supervised agricultural experiences. Presented at the $9^{\text {th }}$ Annual North Central Region American Association of Agricultural Educators Research Conference, University Park, Pennsylvania.

Kneer, A.K., Rice, J.E., Gartin, S.A., LaVergne, D., Kessell, J. (2011). Facebook as an educational tool in an agricultural communications course. Presented at the $9^{\text {th }}$ Annual North Central Region American Association of Agricultural Educators Research Conference, University Park, Pennsylvania.

Rice, J.E., Gartin, S.A. (2010). Effective Classroom Assessment Course for Agricultural Education Teachers. Presented at the $8^{\text {th }}$ Annual North Central Region American Association of Agricultural Educators Research Conference, Manhattan, Kansas.

Rice, J.E., Gartin, S.A. (2010). Advanced Farm Machinery Course for Pre-service Teachers. $8^{\text {th }}$ Annual North Central Region American Association of Agricultural Educators Research Conference, Manhattan, Kansas. October 10, 2010. (Submitted alternate paper).

Rice, J.E., Gartin, S.A. (2010). Effective Classroom Assessment Course for Agricultural Education Teachers. 2010 Southern Association of Agricultural Scientists Research Conference, Corpus Christi, Texas. February 8, 2011. (Submitted).

Rice, J.E., Gartin, S.A. (2010). Revitalizing Agricultural Mechanics Courses in Higher Education. 2010 Southern Association of Agricultural Scientists Research Conference, Corpus Christi, Texas. February 8, 2011. (Submitted).

\section{Magazine Articles:}

Rice, J. (2011, January/February 1). Gambling with student success. West Virginia Ag Ed News and Views, LXI (1), 4-5.

Rice, J. (2008, January/February 1). Creative SAEs: A technological SAE for the technology generation. West Virginia Ag Ed News and Views, LVIII (1), 4-5. 


\section{Research Awards:}

2011 NAAE North Central Region $1^{\text {st }}$ runner up in both open and student division research poster divisions. Rice, J.E., Gartin, S.A., LaVergne, D. (2011). Assessing the agricultural mechanic competencies of former high school agricultural education students.

2011 NAAE North Central Region 2nd runner up student division innovative idea poster. Kneer, A.K., Rice, J.E., Gartin, S.A., LaVergne, D., Kessell, J. (2011). Facebook as an educational tool in an agricultural communications course.

\section{University Teaching Experience:}

Instructor, Agricultural and Extension Education Effective Classroom Assessment (AGEE 493D), WEST VIRGINIA UNIVERSITY, Morgantown, WV 26506.

Responsibilities included: Assisted in the planning, delivery, and evaluation of students' use of proper classroom assessment techniques though the use of a web-based course. Provided relevant information on the proper use of summative and formative assessments in a high school classroom. Shared tools and methods for constructing efficient grading rubrics and the importance of student involvement in the grading process.

Accomplishments: Students were able to identify the important components of diagnostic, formative, and summative assessment and describe techniques that are used to create an inclusive environment where students of all abilities are provided with a quality education.

Instructor, Educational Strategies in Agricultural Education (AGEE 693M), WEST VIRGINIA UNIVERSITY, Morgantown, WV 26506.

Responsibilities included: Assisted in the planning, delivery, and evaluation of students' use of proper classroom teaching techniques and questioning strategies. Shared tools and methods for constructing efficient grading rubrics and the importance of student involvement in the grading process. Shared the importance of inclusion of special need/disabled students in agricultural education. Discussed the importance of student diversity in agriculture.

Accomplishments: Students were able to identify the important components of student assessment, describe teaching techniques that are used to create an inclusive environment where students of all abilities are provided with a quality education. Identify strategies that can be used to ensure that the classroom student population is proportionate to the overall student population diversity.

Instructor, Agricultural and Extension Education Advanced Farm Machinery (AGEE 452), WEST VIRGINIA UNIVERSITY, Morgantown, WV 26506.

Responsibilities included: Assisted in the planning, delivery, and evaluation of students' agricultural mechanic skills. Provided instruction for students during weekly recitation sessions. Collaborated in teamteaching lectures. Shared with students a series of lectures and exercises that will improve their knowledge of various pieces of Agricultural Machinery that encompasses a wide array of agricultural sectors throughout the US.

Accomplishments: Students in the class gained proficiency in the following areas:

- Relate history and ideals of agricultural machinery.

- Identify Agricultural Machinery as it relates to the agricultural industry throughout the United States.

- Identify the importance of machinery in production and entrepreneurial agriculture.

- Identify all aspects of the agricultural machinery industry including: production, maintenance, and sales. 
Instructor, Agricultural and Extension Education Shop Theory \& Methods (AGEE 330), WEST VIRGINIA UNIVERSITY, Morgantown, WV 26506.

Responsibilities included: Assist in the planning, delivery, and evaluation of students' agriculture mechanics skills and their ability to teach high school students and adults the proper safety and use of equipment and techniques in agriculture mechanics. Provide leadership and instruction for students during weekly recitation sessions. Collaborate in team-teaching lectures.

Accomplishments: Students increased their teaching skills and learned how to collaborate cognitive and psychomotor skills when teaching others in an active learning environment.

Instructor, Agricultural and Extension Education Basics of Agriculture Mechanics (AGEE 103), WEST VIRGINIA UNIVERSITY, Morgantown, WV 26506.

Responsibilities included: Assist in the planning, delivery, and evaluation of students' agriculture mechanic skills. Provide instruction for students during weekly recitation sessions. Collaborate in team-teaching lectures. Shared with students the basics of Arc Welding, Mig Welding, Oxy Acetylene Welding, and basic hand tool conditioning.

Accomplishments: Students in the class increased their skill set and were able to complete the basic competencies that surround each of the subject areas.

Graduate Teaching Assistant, Agricultural and Extension Education Directing FFA and SAEs (AGEE 426), WEST VIRGINIA UNIVERSITY, Morgantown, WV 26506.

Responsibilities included: Assist in the planning, delivery, and evaluation of students' knowledge of FFA and SAEs in agricultural education programs. Provide instruction for students during weekly recitation sessions. Collaborate in team-teaching lectures. Shared with students the basics of classroom, laboratory, and supervised agricultural experience programs. Discussed the various degrees and awards that are available to FFA students and the impact that SAE programs plays on the community.

Accomplishments: Students in the class increased their skill set and were able to complete the basic competencies that surround each of the subject areas. Students served as officials for the North Central scholastics contest for West Virginia FFA Association.

Graduate Teaching Assistant, Agricultural and Natural Resources Communications (AGEE 421), WEST VIRGINIA UNIVERSITY, Morgantown, WV 26506.

Responsibilities included: Assist in the planning, delivery, and evaluation of students' oral and written assignments. Provide leadership and instruction for students during weekly recitation sessions. Collaborate in team-teaching lectures. Provide one-on-one and small group instruction for students preparing for oral presentations.

Accomplishments: Students in my group increased their presentations skills by $100 \%$. $75 \%$ of the students in my group ended up being rated in the top $10 \%$ in the class. Student teachers identified this course as one if the most beneficial in student teaching.

\section{Presentations:}

Guest Lecturer, Agricultural and Natural Resources Communications (AGEE 421), WEST VIRGINIA UNIVERSITY, Morgantown, WV 26506.

Responsibilities included: Lectured on the importance of photography and photo editing in agriculture communications and the proper techniques to present photos to clients. Lectured about the principles of teaching and learning.

Guest Lecturer, Clay Battelle High School, Blacksville, WV 26521.

Responsibilities included: Lectured on the impact the combine harvester has had on agriculture in the United States with the Agriculture and Natural Resources II class. Taught an introduction to the FFA lecture to the $8^{\text {th }}$ grade students in the Agriculture Explore class. 


\section{Professional Experience:}

Agriculture Education Teacher, Southern High School, Harwood, MD 20776.

August 2011-Present

Responsibilities included: Certified CASE instructor in Agriculture, Food and Natural Resources; Plant Science; and Animal Science. Taught courses in Foundations of Technology.

Accomplishments: Chartered the Southern High FFA chapter. Increased membership and class enrollment by $200 \%$ after the first year of teaching. Completed greenhouse renovation. Installed and implemented hydroponics facility and community garden.

Awards: Southern High School Golden Apple Award, Southern High School Teacher of the Month for March 2012.

Substitute Teacher, Monongalia County Schools, Morgantown, WV 26505.

Responsibilities included: Taught courses in all disciplines in grades 1-12 in the public school system in Monongalia County, West Virginia.

Student Teacher, Hundred High School, Hundred, WV 26575.

Responsibilities included: Taught courses in agricultural education to students in grades 6-12 that included the following subjects: Agriculture and Natural Resources 1-4, Horticulture, Aquaculture, and Agriculture

Mechanics. Taught an adult education course in agriculture literacy and served as the assistant FFA advisor.

Pet Care Attendant, Paw Prints Veterinary Clinic, Morgantown, WV 26505.

Responsibilities included: Learned the proper techniques of animal care and recovery. Observed surgeries and helped attend to sick and hospitalized patients.

Lab Technician, WVU Rumen Fermentation Profiling Lab, Morgantown, WV 26506.

Responsibilities included: Performed analysis on various feed samples by conducting tests to measure levels of protein, carbohydrates, fats, and sugars. Studied the function and microbes of the ruminant stomach in Holstein Cattle.

Coordinator, Mountaineer Madness Jackpot Show, Morgantown, WV 26506.

Responsibilities included: Founder of a Steer and Heifer show that showcases bovine from Maryland, Ohio, Virginia, West Virginia, and Pennsylvania. In charge of Marketing and Publicizing the show through the Cooperative Extension Service and Beef Producers on the East Coast. Organizing a trade show component that showcases over 24 vendors from the tri-state area that grossed over $\$ 80,000.00$ and managing $30 \mathrm{WVU}$ students that are responsible for the operation of the show. Show coordinator in 2008, 2009, and 2010.

\section{Recruiter, Davis College of Agriculture, Natural Resources and Design, WEST VIRGINIA}

UNIVERSITY, Morgantown, WV.

Responsibilities included: Attended the National FFA Convention in Indianapolis, Indiana in 2008 \& 2009 with the West Virginia University student recruitment booth. Networked with Agriculture Industry leaders and other Universities in attendance. Collected personal information from over 8,000 high school students each year and conveyed the benefits of attending West Virginia University.

\section{Co-Coordinator, 2009 \& 2010 West Virginia FFA Association Agriculture Mechanics Career}

Development Event, WEST VIRGINIA UNIVERSITY, Morgantown, WV.

Responsibilities included: Developed a two day contest for West Virginia FFA students that focused on the national theme of Plant Production Systems with questions from the following categories: Machinery and Equipment System, Industry and Marketing Systems, Structural Systems, and Environmental Natural Resource Systems. The students were tested on cognitive and psychomotor skills. 
Official Judge, 2010 West Virginia North Central Region Scholastic Competition, Farmington, WV. Responsibilities included: Evaluated the participants in the upper classman creed competition on their delivery and understanding of the FFA Creed and selected the winner from the North Central Region that would move on to the state competition.

\section{Honors and Activities:}

West Virginia University, Morgantown, WV.

Organizations:

○ Mountaineer Collegiate FFA -

- Mountaineer Madness Jackpot Show - Coordinator 2008-2010

○ 2008 Jr. Advisor

- Block and Bridle

- National Association of Agriculture Educators

- National Collegiate Horticulture Society

- Davis College of Agriculture Student Council

- West Virginia University Livestock Judging Team

- WVU College of Agriculture, Forestry, and Consumer Sciences Alumni Assoc.

West Virginia Farm Bureau, Buckhannon, WV.

○ 2005 West Virginia Young Farmer of the Year

Monongalia County 4-H, Morgantown, WV.

- 2001 Julian A. Cheslock Stockman of the Year

American Shorthorn Association, Omaha, NE.

○ 2005 National Reserve Champion Extemporaneous Speaker

\section{Professional Affiliations:}

- American Association for Agricultural Education

- Association for Career and Technical Education

- National Association for Agriculture Educators

- Maryland State Education Association

- Gamma Sigma Delta : The Honor Society of Agriculture 